Nano-sized zinc oxide and silver, but not titanium dioxide, induce innate and adaptive immunity and antiviral response in differentiated THP-1 cells

Poon, W. L.

2017

Poon, W L , Alenius , H , Ndika , J , Fortino , V , Kolhinen , V , Mesceriakovas , A , Wang , M , Greco , D , Lähde , A , Jokiniemi , J , Lee , J C-Y , El-Nezami , H \& Karisola , P 2017 , ' Nano-sized zinc oxide and silver, but not titanium dioxide, induce innate and adaptive immunity and antiviral response in differentiated THP-1 cells ' , Nanotoxicology, vol. 11, no. 7 , pp. 936-951 . https://doi.org/10.1080/17435390.2017.1382600

http://hdl.handle.net/10138/311282

https://doi.org/10.1080/17435390.2017.1382600

unspecified

acceptedVersion

Downloaded from Helda, University of Helsinki institutional repository.

This is an electronic reprint of the original article.

This reprint may differ from the original in pagination and typographic detail.

Please cite the original version. 


\section{Nanosized zinc oxide and silver, but not titanium dioxide, induce innate and adaptive immunity and antiviral response in differentiated THP-1 cells}

Wing-Lam Poon ${ }^{1}$, Harri Alenius ${ }^{2,3}$, Joseph Ndika ${ }^{2}$, Vittorio Fortino ${ }^{4}$, Vesa Kolhinen ${ }^{5}$, Arūnas Meščeriakovas ${ }^{6},{\text { Mingfu } \text { Wang }^{1} \text {, Dario Greco }}^{4,7}$, Anna Lähde ${ }^{6}$, Jorma Jokiniemi $^{6}$, Jetty Chung-Yung Lee $^{1}$, Hani El-Nezami ${ }^{1,8 *}$, Piia Karisola ${ }^{2}$

${ }^{1}$ School of Biological Sciences, University of Hong Kong, Pokfulam Road, Hong Kong

${ }^{2}$ Department of Bacteriology and Immunology, University of Helsinki, Haartmaninkatu 3, 00290 Helsinki, Finland

${ }^{3}$ Institute of Environmental Medicine (IMM), Karolinska Institutet, Stockholm 171 77, Sweden

${ }^{4}$ Institute of Biotechnology, University of Helsinki, Helsinki 00100, Finland

${ }^{5}$ Finnish Environment Institute (SYKE), Mechelininkatu 34a, 00260 Helsinki, Finland

${ }^{6}$ Department of Environmental Science, University of Eastern Finland, 70211 Kuopio, Finland

${ }^{7}$ Faculty of Medicine and Life Sciences, University of Tampere, P.O. Box 100, University of

Tampere, Finland

${ }^{8}$ Institute of Public Health and Clinical Nutrition, School of Medicine, University of Eastern Finland, P.O. Box 1627, 70211 Kuopio, Finland

*Address correspondence to Piia.Karisola@Helsinki.fi or to elnezami@hku.hk

Author's contact information:

BSc. Wing-Lam Poon, Tel. (852) 2299 0834, vpoon11@connect.hku.hk Prof. Harri Alenius, Tel. (358) 2941 26460, harri.alenius@helsinki.fi

PhD Joseph Ndika, Tel. (358) 2941 26215, joseph.ndika@helsinki.fi

PhD Vittorio Fortino, Tel. (358) 4560 88478, vittorio.fortino@helsinki.fi

PhD Vesa Kolhinen, Tel. (358) 2952 51292, vesa.kolhinen@ymparisto.fi

MSc/PhD Arunas Mesceriakovas, Tel. (358) 294453258, arunas.mesceriakovas@uef.fi

Assoc. Prof. Anna Lähde, Tel. (358) 2944 53771, anna.lahde@uef.fi

Assoc. Prof. Mingfu Wang, Tel. (852) 2299 0338, mfwang@hku.hk 
Assoc. Prof. Dario Greco, Tel. (358) 2941 58952, dario.greco@helsinki.fi

Prof. Jorma Jokiniemi, Tel. (358) 2944 53738, jorma.jokiniemi@uef.fi

Assoc. Prof. Jetty Chung-Yung Lee, Tel. (852) 2299 0318, jettylee@hku.hk

Prof. Hani S. El-Nezam, Tel. (852) 2299 0835, elnezami@hku.hk

Assoc. Prof. Piia Karisola, Tel. (358) 2941 26601, piia.karisola@helsinki.fi

Word count: 7466 


\section{Abstract}

Nano-sized metal oxides are currently the most manufactured nanomaterials (NMs), and are increasingly used in consumer products. Recent exposure data reveal a genuine potential for adverse health outcomes for a vast array of NMs, however the underlying mechanisms are not fully understood. To elucidate size-related molecular effects, differentiated THP-1 cells were exposed to nano-sized materials $\left(\mathrm{n}-\mathrm{TiO}_{2}, \mathrm{n}-\mathrm{ZnO}, \mathrm{n}-\mathrm{Ag}\right)$, or their bulk-sized $\left(\mathrm{b}-\mathrm{ZnO}, \mathrm{b}-\mathrm{TiO}_{2}\right)$ or ionic $(\mathrm{i}-\mathrm{Ag})$ counterparts, and genome-wide gene expression changes were studied at low-toxic concentrations ( $<15 \%$ cytotoxicity). $\mathrm{TiO}_{2}$ materials were non-toxic in MTT assay, inducing only minor transcriptional changes. $\mathrm{ZnO}$ and $\mathrm{Ag}$ elicited dose-dependent cytotoxicity, wherein ionic and particulate effects were synergistic with respect to $\mathrm{n}-\mathrm{ZnO}$-induced cytotoxicity. In gene expression analyses, $6 \mathrm{~h}$ and $24 \mathrm{~h}$ samples formed two separate hierarchical clusters. $\mathrm{N}-\mathrm{ZnO}$ and $\mathrm{n}-\mathrm{Ag}$ shared only $3.1 \%$ and $24.6 \%$ differentially expressed genes (DEGs) when compared to corresponding control. All particles, except $\mathrm{TiO}_{2}$, activated various metallothioneins. At $6 \mathrm{~h}, \mathrm{n}-\mathrm{Zn}, \mathrm{b}-\mathrm{Zn}$ and n-Ag induced various immunity related genes associating to pattern recognition (including toll-like receptor), macrophage maturation, inflammatory response (TNF, IL-1beta), chemotaxis (CXCL8) and leucocyte migration (CXCL2-3, CXCL14). After 24h exposure, especially n-Ag induced the expression of genes related to virus recognition and type I interferon responses. These results strongly suggest that in addition to ionic effects mediated by metallothioneins, $\mathrm{n}-\mathrm{Zn}$ and $\mathrm{n}-\mathrm{Ag}$ induce expression of genes involved in several innate and adaptive immunity associated pathways, which are known to play crucial role in immuno-regulation. This raises the concern of safe use of metal oxide and metal nanoparticle products, and their biological effects.

Keywords: $\mathrm{ZnO}, \mathrm{Ag}$, nanomaterials, immune system, transcriptomics 


\section{Introduction}

Nanotechnology continuously offers new, engineered nanomaterials (NMs) with outstanding properties to various industrial sectors and medicine but increasingly also to consumer products such as clothing, cosmetics and food. Metal oxides and metal-based nanoparticles are one of the largest group of used nanoparticles (one dimension less than $100 \mathrm{~nm}$ ), of which silver (Ag) NMs alone are manufactured approximately 320 tons in each year (Nowack et al., 2011). When the size of metal particles decreases, their reactive surface area increases, and therefore, NMs are thought to cause more severe adverse effects in organisms than micrometer size materials. There is ongoing debate about the role of released ions from metal oxides and metal nanoparticles, that have been found to be the main cause of their toxicity (Ma et al., 2013, Sharma et al., 2014, Utembe et al., 2015). Even though ions do not easily pass the cell membranes by themselves, toxic intracellular concentrations are attained via a "Trojan horse" mechanism, wherein, metal ions are released from NMs that cross the cell membrane (Hsiao et al., 2015). However, ion releasing potential with enhanced solubility and dissolution cannot alone account for the toxic effects observed, since numerous studies have shown additional effects depending on the characteristics of NMs both in vivo and in vitro (Kruszewski et al., 2011). Even though metal oxides are amongst the most commercialized nanomaterials, studies concerning other than ion-dependent effects at the cellular and molecular levels are rather limited and the mechanisms behind metal oxide toxicity are far from being understood.

Some metal oxides are not reported to be harmful in biological systems, whereas others are reported to increase cytotoxicity by enhancing oxidative stress, apoptosis, cytokine production, DNA damage and cell cycle arrest (AshaRani et al., 2009, Tuli et al., 2015). Even the same material may have various effects in different environments due to particle properties (size, shape, charge) and prevailing interactions. Titanium dioxide $\left(\mathrm{TiO}_{2}\right)$ particles are often considered stable, insoluble and of low toxicity particles, but in certain in vivo set-ups, they have been reported to cause pulmonary toxicity and lung inflammation (Shi et al., 2013). Zinc oxide (ZnO), on the contrary, is considered to 
have cytotoxic, inflammatory and genotoxic effects mostly through its dissolution and generation of reactive oxygen species (ROS) (Roy et al., 2015). In a few studies, ZnO NMs are shown to increase the expression of inflammatory markers (e.g. ICAM-1, IL-8 and MCP-1) (Gojova et al., 2007), and also to enhance the production of cytokines (IFN- $\gamma$, TNF and IL-12) (Hanley et al., 2009). Silver (Ag) NMs are the most widely studied metal nanoparticles, and they are known to interact with intracellular components leading to oxidative stress, consequently high ROS and inflammation that eventually leads to necrotic or apoptotic cell death (Zhang et al., 2016).

As NMs have size comparable to biological structures, they are able to enter the cells passively, or actively via cellular uptake (endocytosis), and have interactions with intracellular compartments that can lead to variable biological responses (Gliga et al., 2014). Previous studies have also linked toxicity of certain NMs to inflammation, an important immune response that aims to eliminate invading foreign matter, but may become harmful when overly expressed (Tuli et al., 2015). This leads to the production of cytokines, chemokines and activation of the immune system $i n$ vivo. However, these crucial steps that occurs during the first hours are not well characterized even in vitro. The published results are often hard to compare because of the variation in the particle size or modifications, differences in cell types or used conditions, and versatile analyses. Even when studies describe several particles in the same settings usually utilize molar particle concentrations that often transcribe to the lethal-dose effects for certain particles.

To shed more light on these issues, we selected three well-characterized commercially available NMs and titrated their concentrations so that they induced a maximum cell cytotoxicity of 15\%. We used titanium dioxide $\left(\mathrm{n}-\mathrm{TiO}_{2}\right)$, zinc oxide $(\mathrm{n}-\mathrm{ZnO})$, and polyvinylpyrrolidone-coated silver (n-Ag) and compared the results to their bulk or ionic counterparts (b- $\mathrm{TiO}_{2}, \mathrm{~b}-\mathrm{ZnO}$ and $\mathrm{i}-\mathrm{Ag}$ ) to identify possible size- or ion-specific effects. We exposed monocyte-derived THP-1 macrophages with these particles, and performed global gene expression analyses to evaluate their cellular mechanisms and responses at two different time points, $6 \mathrm{~h}$ and $24 \mathrm{~h}$, after the NM exposure. Our 
results provide concise understanding of the cellular functions and a number of candidate genes, signalling pathways and molecular mechanisms, how intracellular NMs interact with different component in the cytosol, mitochondrion and in the nucleus. Overall, the understanding of these particle-specific mechanisms offer tools for NM carrier design and also contributes to better risk assessment of NMs. 


\section{Methods}

\section{Particles and their characterization}

Nano-sized rutile/anatase $(90 / 10 \%)$ titanium dioxide $\left(\mathrm{n}-\mathrm{TiO}_{2}\right)$ and zinc oxide $(\mathrm{n}-\mathrm{ZnO})$ were purchased from Nanostructured \& Amorphous Materials, Inc. (Houston, USA). Nano-sized PVPcoated silver in water ( $\mathrm{n}-\mathrm{Ag}$ ) was purchased from NanoComposix, (San Diego, USA), titanium dioxide ( $\left.\mathrm{n}-\mathrm{TiO}_{2}\right)$ from Sigma-Aldrich (Schnelldoff, Germany), zinc oxide (n-ZnO) from CamdenGrey Essential Oils, Inc. (Doral, USA), and silver nitrate $\left(\mathrm{AgNO}_{3}\right)$ from Sigma-Aldrich (USA). Properties of $\mathrm{n}-\mathrm{TiO}_{2}, \mathrm{~b}-\mathrm{TiO}_{2}, \mathrm{n}-\mathrm{ZnO}, \mathrm{b}-\mathrm{ZnO}$ and $\mathrm{n}-\mathrm{Ag}$ provided by the vendors are shown in Table 1.

The samples of the freshly made particle suspensions in both water and in complete media (cRPMI, see Supplementary Material, methods) were taken on a holey carbon copper grid (SPI Supplies, Inc.). The primary and agglomerate size of the particles was studied with microscopy (SEM, Zeiss Sigma HD-VP) operated at $2 \mathrm{kV}$ acceleration voltage and the transmission electron microscopy (TEM, Jeol JEM-2100F) operated at $200 \mathrm{kV}$ acceleration voltage. The diameter of the agglomerates was obtained by (hand) fitting method with a spline and by enclosing the projected area, which was used to calculate the area-equivalent diameter of a circle/sphere. Additional methods for the particle characterization are in the Supplementary Material.

\section{Particle dispersions}

The $\mathrm{n}-\mathrm{TiO}_{2}, \mathrm{~b}-\mathrm{TiO}_{2}, \mathrm{n}-\mathrm{ZnO}$ and b-ZnO particles were weighed into autoclaved glass tubes. Stock dispersions $(1 \mathrm{mg} / \mathrm{ml})$ were prepared in cRPMI, followed by $20 \mathrm{~min}$ of continuous sonication in Elmasonic $\mathrm{S} 15 \mathrm{H}$ bath sonicator (frequency $37 \mathrm{kHz}$, effective power $35 \mathrm{~W}$ with maximum peak performance $280 \mathrm{~W}$, Tovatech LLC South Orange, NJ, USA) at $30^{\circ} \mathrm{C}$. Final dispersions were prepared from serial dilution of the stock in cRPMI followed by another $20 \mathrm{~min}$ sonication at $30^{\circ} \mathrm{C}$ just before the cell experiment. 
The $\mathrm{n}-\mathrm{Ag}$ was a $1 \mathrm{mg} / \mathrm{ml}$ stock dispersion in water, and stored at $4{ }^{\circ} \mathrm{C}$ in dark. Before use, the stock was shaken vigorously by hand for 30s to ensure homogeneity. Final dispersions were prepared by dilution in complete media. Silver ion solution (i-Ag), $\mathrm{AgNO}_{3}$, was first dissolved in Milli-Q water to form a $0.3 \%$ stock solution. The stock solution was then filtered through a $0.2 \mu \mathrm{m}$-pore-sized membrane filter (Pall Corporation, USA). Final solutions were prepared by serial dilutions in culture medium. Used concentrations were $0.05 \%, 0.005 \%, 0.0005 \%$ and $0.00005 \%$. These concentrations were selected to cover the high-end of dissolution in water reported by the vendor and potentially higher dissolution in media.

All dispersions were vortexed for $10 \mathrm{~s}$ after sonication, 5s during serial dilutions and before dosing the cells. Concentrations ranging from 0.1 to $100 \mathrm{ug} / \mathrm{ml}$ were used depending on the type of experiments.

\section{Statistical Analyses of mRNA Levels}

Triplicate measurements were made for each treatment. The data was analysed by GraphPad Prism (version 6) by one-way analysis of variance (ANOVA) using the Tukey test or Mann-Whitney t-test. Significance was indicated by $* \mathrm{P}<0.05$, $* * \mathrm{P}<0.01$, *** $\mathrm{P}<0.001$, $* * * * \mathrm{P}<0.0001$. Values were expressed as mean \pm standard deviation (SD).

\section{Microarray-based Expression Profiling}

Three samples per group with RNA integrity number (RIN) 8 or higher were used for microarray hybridization. Two-Color Microarray-Based Gene Expression Analysis protocol (version 6.5), was used for all the samples, starting with 200 ng of total RNA. Oligo-dT (T7) primed cDNA (Quick Amp Labeling Kit, Two-color, Agilent) was amplified and labelled using fluorescently labelled dNTPnucleotides (Cy3 and Cy5) and T7 RNA Polymerase, and yielded products were purified by Qiagen's RNeasy mini spin columns (Qiagen, GmbH, Hilden, Germany). RNA Spike-In Kit was used to 
monitor the success of the labelling. $300 \mathrm{ng}$ of labelled samples from two different groups were always combined per array, and fragmented cRNA was hybridized to microarray slides (Agilent technologies, Sure Print G3 Human GE v3 8x60K Kit, USA) for $17 \mathrm{~h}$ at $65^{\circ} \mathrm{C}$. After the washings, the slides were scanned with Agilent DNA microarray Scanner (Agilent Technologies, DNA Microarray Scanner with Surescan High-Resolution Technology, model G2505C, USA) and sample and background intensities were obtained using Agilent Feature Extraction Software (V11.0.1.1).

The median signal intensities of each sample were imported into Chipster's R-based graphical interface (Kallio et al., 2011). After quantile normalization, the dye-dependent batch effect was removed by ComBat (Johnson et al., 2007). The linear model Limma (Ritchie et al., 2015) was used to fit to the data, and empirical Bayes t-test coupled with Benjamini Hochberg FDR adjustment was used to compare the groups of different NM samples. Genes were defined as being differentially expressed after satisfying a minimum fold change of \pm 1.5 and a maximum, Benjamini-Hochberg adjusted $\mathrm{P}$ value of 0.01 . The microarray data produced in this study is available on request from the authors.

\section{Heat maps, Venn Diagrams and pathway analyses.}

Microarray-based gene expression profiling, followed by differential expression analysis in specific contrast sets, was carried out as described in the Supplementary Materials, Methods section. Hierarchical clustering of differentially expressed genes (DEGs) was done within the Perseus data analysis platform (Tyanova et al., 2016). DEGs from the $6 \mathrm{~h}$ and $24 \mathrm{~h}$ exposures were independently Z-score normalized. The Euclidean method and the k-means algorithm were respectively used to determine the distance between two dataset points and to define the distance between two clusters. A hierarchical cluster of the top 50 DEGs (based on adj. p-values) are depicted in the form of heatmaps for each time point. Upregulated genes (red) are those genes that have a positive standard deviation from the genes mean expression across all exposures, and vice versa for downregulated genes (green). 
Venn diagrams to evaluate the distribution of DEGs between specified contrast sets were created using Venny (Oliveros, 2007-2015). 


\section{Results}

\section{Particle characterization, agglomeration and dosimetry modeling}

Dispersed particles were studied by dynamic light scattering (DLS). The hydrodynamic particle sizes in cRPMI were relatively large compared to the physical diameter reported by the suppliers, and additionally, the particle size of nano- $\mathrm{ZnO}$ and bulk $\mathrm{ZnO}$ could not be reliably measured, since the suspensions contained very large particles (above $1 \mu \mathrm{m}$ ) (see Supplementary Material, Methods and Table S1). The suspensions were not very stable, as the zeta potential values of the suspensions were all around $-10 \mathrm{mV}$ which is relatively close to the zeta potential value of the pure cRPMI. Therefore, the analysis of $\mathrm{ZnO}$ and $\mathrm{TiO}_{2}$ particles was carried out in ion-exchanged water, and although large agglomerates were again observed, the zeta-potential values of $\mathrm{TiO}_{2}$ suspensions were measurable.

Scanning (SEM) and transmission electron microscopy (TEM) were used to study the particle shape (Supplementary Material, Figure S1) and geometric mean diameter of the primary particles, which corresponded to the sizes given by the vendor (Table 2), with the exeption of n-Ag, which was impossible to measure due to the extensive formation of salt crystals on the EM grid. The obtained sizes of primary particles, and agglomerate size distributions were used for the dosimetry modelling to evaluate the actual dose of particles to the cell at the well bottom (DeLoid et al., 2017). N/b-TiO 2 $(100 \mu \mathrm{g} / \mathrm{ml})$ and $\mathrm{n} / \mathrm{b}-\mathrm{ZnO}(10 \mu \mathrm{g} / \mathrm{ml})$ yielded quite comparable bottom concentrations $(2.2$ and 0.8 $\mathrm{mg} / \mathrm{ml}$ for nanosized, and 5.7 and $7.0 \mathrm{mg} / \mathrm{ml}$ for bulk-sized particles, respectively) in $3-5 \mathrm{~h}$, whereas $\mathrm{n}-\mathrm{Ag}(1 \mu \mathrm{g} / \mathrm{ml})$ reached its bottom concentration $(1 \mu \mathrm{g} / \mathrm{ml})$ a little slower (at $7 \mathrm{~h})$ (Supplementary Material, Figure S2). It was also modelled that only $1.1 \%$ of $\mathrm{n}-\mathrm{Ag}$ was deposited during the incubation time, whereas the corresponding deposition was $69.7 \%$ for b-ZnO (Supplementary Material, Figure S2).

Viability and cytotoxicity of differentiated THP-1 cells 
Differentiated THP-1 cells were incubated with various concentrations of NMs $(0.1,1,10,30$ and $100 \mu \mathrm{g} / \mathrm{ml}$ ) for $24 \mathrm{~h}$, and their viability was assessed by MTT assay (Figure 1(A)). Treatment of cells with $\mathrm{n} / \mathrm{b}-\mathrm{TiO}_{2}$ particles did not change their viability, while n/b- $\mathrm{ZnO}, \mathrm{n}-\mathrm{Ag}$ and $\mathrm{i}-\mathrm{Ag}$ induced dosedependent cytotoxicity starting from 10 or $30 \mu \mathrm{g} / \mathrm{ml}$ (Figure $1(\mathrm{~A})$ ). The largest effect was seen with $\mathrm{AgNO}_{3}$, which caused $100 \%$ cell death already at the concentration of $30 \mu \mathrm{g} / \mathrm{ml}$. N/b-ZnO and n- $\mathrm{Ag}$ induced similar cytotoxicity at 30 and $100 \mu \mathrm{g} / \mathrm{ml}$ concentrations. Significant difference in viability within the elemental group was only observed between $\mathrm{b}-\mathrm{ZnO}$ and $\mathrm{n}-\mathrm{ZnO}$ at $100 \mu \mathrm{g} / \mathrm{ml}$ concentration, with $\mathrm{n}-\mathrm{ZnO}$ being more cytotoxic than $\mathrm{b}-\mathrm{ZnO}$. Based on the MTT assay, microarray analysis was carried out on exposures corresponding to the maximum nanomaterial concentration at which $>85 \%$ cell viability was conserved: $1 \mu \mathrm{g} / \mathrm{ml}$ for $\mathrm{AgNO}_{3}, 10 \mu \mathrm{g} / \mathrm{ml}$ for $\mathrm{ZnO}$ particles and for $\mathrm{n}-\mathrm{Ag}$, and 100 $\mu \mathrm{g} / \mathrm{ml}$ for $\mathrm{TiO}_{2}$ particles.

To further investigate the possible contribution of released ions within the incubation, another MTT experiment was performed. The particles were incubated with cell medium alone for $24 \mathrm{~h}$, and yielded supernatants were used to expose fresh, differentiated THP-1 cells for $24 \mathrm{~h}$ (Figure 1(B)). The supernatant of $\mathrm{n}-\mathrm{ZnO}$ suspension significantly decreased cell viability but the effect was smaller than with cells and particles together, showing that extracellular ion release is important for the cytotoxicity of $\mathrm{n}-\mathrm{ZnO}$ but not for the b-ZnO nor $\mathrm{n}-\mathrm{Ag}$, whose supernatants were not able to induce cytotoxicity alone (Figure 1(C)).

\section{Cytokine expression by RT-PCR}

To study the effects of NMs on pro-inflammatory cytokine expression, we measured the relative gene expressions of certain key cytokines including IL- $1 \beta$ and TNF at $6 \mathrm{~h}$ and $24 \mathrm{~h}$ after the exposure. No cytokine expression was detected from n- $\mathrm{TiO}_{2}$ - or b- $\mathrm{TiO}_{2}$-exposed cells at either time points. For all other particles, low expression of IL-1 $\beta$ and TNF cytokines was already detected at $6 \mathrm{~h}$. Both n- $\mathrm{ZnO}$ and $\mathrm{b}-\mathrm{ZnO}$ caused time-dependent induction of both cytokines at cytotoxic concentrations, with n- 
$\mathrm{ZnO}$ triggering significantly more efficient IL-1 $\beta$ and TNF gene expression when compared to b$\mathrm{ZnO}$, especially at $24 \mathrm{~h}$. The cells treated with n-Ag also induced the expression of IL-1 $\beta$ and TNF, and $\mathrm{AgNO}_{3}$ but did not induce highly in cytokine expressions at any tested concentrations (Supplementary Material, Figure S3).

\section{Transcriptomics}

The NM exposures were characterized in detail with genome-wide gene-expression microarray to compare samples treated with different particles for $6 \mathrm{~h}$ or for $24 \mathrm{~h}$ to the corresponding non-treated control samples (Supplementary Material, Table S2-S3. All 6h samples, and also all 24h samples were clustered together forming two main groups (Figure 2(A)). In the principal component analysis (PCA) all samples in one group clustered together, and $6 \mathrm{~h}$ and $24 \mathrm{~h}$ samples were highly separated along the PCA2 (Figure 2(B)). At both time points, the control samples were in close proximity of the $\mathrm{n}-\mathrm{TiO}_{2}$ and $\mathrm{b}-\mathrm{TiO}_{2}$ samples (Figure 2(B)).

To identify the DEGs, each particle was first compared to the corresponding, untreated control sample (lists of DEGs in Supplementary Material, Tables S1-S2). The DEGs of a NM were then compared with corresponding control particle at the same time point. No significant DEGs were observed in response to $\mathrm{TiO}_{2}$ exposures, and therefore they are excluded from further analyses. $\mathrm{Ag}$ particles shared only $3.1 \%$ and $4.1 \%$ of DEGs at $6 \mathrm{~h}$ and $24 \mathrm{~h}$ time points, respectively, whereas $\mathrm{Zn}$ particles shared $20.8 \%$ and $24.6 \%$ at $6 \mathrm{~h}$ and $24 \mathrm{~h}$ time points, respectively (Figure $2(\mathrm{C})$ ). At $6 \mathrm{~h}, \mathrm{i}-\mathrm{Ag}$ did not have any specific DEGs, and also n-Zn had zero and five DEGs at $6 \mathrm{~h}$ and $24 \mathrm{~h}$ time points, respectively (Figure 2(C)).

\section{Clustering and pathway analyses}

When the NMs treated for $6 \mathrm{~h}$ were annotated and clustered, three main groups were identified, $\mathrm{b}-\mathrm{Zn}$ and $\mathrm{n}-\mathrm{Ag}$ formed a cluster with highly upregulated genes, $\mathrm{n}-\mathrm{Zn}$ clustered in the middle and all the 
other particles formed the third, mostly down-regulated gene cluster within the 50 most significantly DEGs (Figure 3(A)).

Venn analysis separated the DEGs from all four 6h exposures into six main groups: bZn (443 genes), bZn+nAg (183 genes), nAg (118) genes, bZn+nZn (43 genes) and nZn+bZn+nAg (11 genes). Enriched pathways represented by these genes are depicted in Figure 3(B). The group specific for bZn had mainly genes, which were involved in lymphocyte activation, differentiation and migration. The 183 common genes for $\mathrm{b}-\mathrm{Zn}$ and $\mathrm{n}-\mathrm{Ag}$ were involved in protein folding, and processing of unfolded or incorrectly folded proteins. The 112 genes, which were common for b-/n-Zn and n-Ag were found to mostly represent inflammatory responses, leucocyte migration, defence and in cellular responses to bacterial molecules (e.g. lipopolysaccharide). Also, 11 genes, which were common to all $\mathrm{Zn}$ and $\mathrm{Ag}$ particles showed high correlation to ionic responses to zinc and other metal ions. No enriched pathways were significantly represented by the 118 genes that were unique to $\mathrm{nAg}$ and the 43 genes corresponding to $\mathrm{bZn}+\mathrm{nZn}$. (Figure 3(B))

When similar analysis was performed for the cell samples treated with the NMs for 24h, again three main clusters were formed in the heatmap of the 50 most significantly DEGs (Figure 4(A)). At this time point, $\mathrm{n}-\mathrm{Ag}$ was separated from the others, $\mathrm{b}-\mathrm{Zn}$ and $\mathrm{n}-\mathrm{Zn}$ formed their own cluster in the middle and all the other samples were included in the third cluster (Figure 4(A)).

At the $24 \mathrm{~h}$ time point, the DEGs were again analysed in the pathway analysis tool, and there were again four groups of DEGs, which were statistically significant based on their adjusted p-values. Ionic $\mathrm{Ag}\left(\mathrm{AgNO}_{3}\right)$, which clustered with control and $\mathrm{TiO}_{2}$ samples in the heatmap, had 62 specific genes, which are mainly involved in lymphocyte activation and differentiation (Figure 4(B)). Also bZn had individual, significant group of 78 DEGs functioning on progesterone metabolism and chemotaxis. The $671 \mathrm{n}$-Ag-specific DEGs, had high importance in viral responses, interferon production and innate immunity. The fourth group, which was shared with b-Zn particles and with n- 
Ag (77 genes) showed high representation of ion-response pathways to zinc and cadmium, and also to the regulation of IL-1 $\beta$ secretion. (Figure 4(B))

We then studied each of the particles at both time points, and associated their DEGs with corresponding biological pathways. The $\mathrm{n}-\mathrm{Zn}$ and $\mathrm{i}-\mathrm{Ag}$ showed almost only genes associated to ionic responses, chemotaxis and inflammation, and also b-Zn and n-Ag shared the responses to ions at both $6 \mathrm{~h}$ and $24 \mathrm{~h}$ time points (Supplementary Material, Figure S4(A), S5(A)). Additionally, b-Zn exposure induced pathways on leukocyte activation, cell adhesion and regulation of metabolic processes at $6 \mathrm{~h}$, and genes on progesterone metabolism and chemotaxis were specific for $24 \mathrm{~h}$ time point (Supplementary Material, Figure S4(B)). Similarly, n-Ag showed activating pathways that regulate cell metabolism, fever and cytokine expressions after $6 \mathrm{~h}$ of exposure, whereas $18 \mathrm{~h}$ later, the $\mathrm{n}-\mathrm{Ag}$ was mainly activating interferon and some homeostatic responses (Supplementary Material, Figure S5(B)).

We next studied in more detail the previously identified four, statistically significant DEG groups both at $6 \mathrm{~h}$ and at $24 \mathrm{~h}$ (identified in Figures 3 and 4 ) by opening up the genes included in each pathway. At both time points, all of the groups (except n-Zn and i-Ag at $24 \mathrm{~h}$ ) were heavily associated with metal ion responses and even nine of the gene products were different isoforms of mammalian metallothionein 1 (isoforms A, B, E, F, G, H, L, M, X) (Figure 5(A-B)). At 6h, the groups exposed to $\mathrm{b}-\mathrm{Zn}, \mathrm{n}-\mathrm{Zn}$ and to $\mathrm{n}-\mathrm{Ag}$ showed differentially enhanced expression of inflammatory and chemotactic proteins including IL-1 $\beta$, TNFAIP3, NF-кBIA, CCL1/3/30, CCR7 and CXCL2/3/14 (Figure 5(C)). After 24h of particle exposures, n-Ag induced responses to extracellular stimulus, virus, TNF pathway and cell surface markers including DEGs for ICAM1, CD86 and CXCR1 (also known as IL-8R) (Figure 5(D)).

Although b-Zn was used as a bulk-size control particle in this study, it had specific DEGs at both time points. After $6 \mathrm{~h}$ of exposure with b-Zn, lymphocyte activation was enhanced by various cell adhesion molecules including integrins ITGAV, ITG4 and ITG6, vinculin (VCL) and CD58 
(called also LFA-3), of which some play a role in blood coagulation process (Supplementary Material, Figure S6(A)). At 24h, b-Zn induced the expression of enzyme genes playing role in aldo/keto metabolism, including progesterone modifications (AKR1C3, AKR1C1), and genes for cholesterol metabolism including STAR (steroidogenic acute regulatory protein), and chemotaxis including CXCL12 and CCL19. (Supplementary Material, Figure S6(B))

After $6 \mathrm{~h}$ of exposure, $\mathrm{b}-\mathrm{Zn}$ and $\mathrm{n}-\mathrm{Ag}$ shared the expression of genes involved in the unfolding of proteins and regulating metabolic processes, which included DUSP1/2/5 (dual specificity protein phosphatases), heat shock proteins (HSP), and growth arrest and DNA damage (GADD) associated genes (Supplementary Material, Figure S6(C)). The i-Ag also induced specific pattern of genes regulating lymphocytes and inflammatory responses at $24 \mathrm{~h}$ after exposure (Supplementary Material, Figure S6(D)). They included PTPN22 (protein tyrosine phosphatase, non-receptor type), MERTK (proto-oncogene tyrosine kinase MER), NOD2 which is called also CARD15 (nucleotide-binding oligomerization domain-containing protein 2), BLNK (B-cell linker), and acute-phase reactants ORM1 and ORM2 (alpha-1-acid glycoprotein 1/2) (Supplementary Material, Figure S6(D)).

\section{Validation}

The microarray results were validated by RT-PCR, and the expression levels of MT1F, CXCL8 and CCL20 corresponded well to that which was observed with microarray analysis (Figure 6). 


\section{Discussion}

NMs have great potential and interest in several fields from material development to future medical therapies, but their involvement and mechanisms in biological systems needs to be understood before their safe use. To avoid examination of cell death induced differences in transcriptomic profiles, we selected concentrations causing maximum of $15 \%$ of cytotoxicity to study the responses of NMs at $6 \mathrm{~h}$ and $24 \mathrm{~h}$ after the exposure. These particle concentrations varied between $1-100 \mu \mathrm{g} / \mathrm{ml}$ but showed quite similar effective concentrations $(0.8-2.2 \mathrm{mg} / \mathrm{ml}$, except $11.6 \mu \mathrm{g} / \mathrm{ml}$ for $\mathrm{n}-\mathrm{Ag})$ during the exposure near the cell surface at the bottom of the well based on the dosimetry modelling (Supplemental Material, Figure S2). We found that both nano- and bulk-sized $\mathrm{TiO}_{2}\left(\mathrm{n}-\mathrm{TiO}_{2}, \mathrm{~b}-\mathrm{TiO}_{2}\right)$ particles were very inert, whereas $\mathrm{Zn}(\mathrm{n}-\mathrm{ZnO}, \mathrm{b}-\mathrm{ZnO})$ and $\mathrm{Ag}(\mathrm{n}-\mathrm{Ag}$, i-Ag) materials had particlespecific but also shared effects in the cell metabolism and gene expressions.

It is widely accepted that metal particles release ions, but distinguishing the functional effects of the ions from that of the particle itself has been more difficult. Particles form several intermolecular interactions with surrounding buffer by van der Waals and electrostatic forces, and by hydrogen bonds (He and Alexandridis, 2015). Various proteins in biological fluids (e.g. cytosol) make these interactions even more complicated, and sometimes these interactions lead to protein aggregation and unfolding (Deng et al., 2011). Even fetal bovine serum in cell culture media can form a protein corona around the NMs changing their cytotoxicity, reactivity, diffusion properties and cellular uptake. Lopes et al. (Lopes et al., 2016) showed that $\mathrm{ZnO}$ and Ag NMs had different toxicity patterns as their ionic counterparts $\left(\mathrm{ZnCl}_{2}\right.$ and $\left.\mathrm{AgNO}_{3}\right)$, and that a mixture of $\mathrm{NM}$ and ions showed a synergistic effect by relying on the interaction between nanoparticles and ions. This is an important point while doing long term exposures, because particle dissolution relates their fate and toxicity. In our studies, we were able to show that ions released from $\mathrm{n}-\mathrm{ZnO}$ had cytotoxic effects in the cell, which were cumulative with the particulate effects of $\mathrm{ZnO}$ NM (Figure 1(B)). Although we did not observe the same for $\mathrm{Ag}$ or $\mathrm{TiO}_{2} \mathrm{NMs}$, we cannot exclude this possibility at different concentrations and 
circumstances. Additionally, based on the transcriptomic analyses the responses to ions were triggered at $6 \mathrm{~h}$ for $\mathrm{n}-\mathrm{ZnO}$ and at both $6 \mathrm{~h}$ and $24 \mathrm{~h}$ for b-ZnO and $\mathrm{n}-\mathrm{Ag}$ (Supplementary Material, Figures $\mathrm{S} 3$ and $\mathrm{S} 4$ ), suggests that $\mathrm{n}-\mathrm{ZnO}$ mediates a fast ion release as opposed to a sustained release of ions by both b-ZnO and $\mathrm{n}-\mathrm{Ag}$. The lower number of ion-associated genes triggered by $\mathrm{i}$-Ag reflects the previously known limited intracellular accessibility to free ions.

Both $\mathrm{n}-\mathrm{ZnO}$ and $\mathrm{b}-\mathrm{ZnO}$ exposures cause various responses to cells, which is not surprising, as approximately 3000 proteins are thought to bind to zinc in vivo corresponding even up to $10 \%$ of the human proteome (Kimura and Kambe, 2016). Zn ions are important cofactors in structural metalloproteins, where they are stored in intracellular vesicles, and homeoproteins called metallothioneins (MT) keep their cytosolic concentration very low (pM-nM) by binding up to 20 monovalent or 7 divalent heavy metal ions per one MT molecule (Kimura and Kambe, 2016). Studies with nine differently modified $\mathrm{ZnO}$ NMs also showed metallothioneins being the only common group of differentially expressed genes (DEGs), which were responsible for the major $\mathrm{ZnO}$-derived effects in three different cell lines (Tuomela et al., 2013). Also in our microarray studies, metallothioneins (MTs) were induced after $\mathrm{n}-/ \mathrm{b}-\mathrm{Zn}$ exposures, and additionally their expression was highly upregulated after treating the cells with n-Ag and i-Ag (Figures 2-4). It is published that MTs take part in metal ion detoxification and protection against free radicals during oxidative stress (Krizkova et al., 2016). At least, cadmium and copper ions can compete with $\mathrm{Zn}$ ions for the binding to the metal responsive element (MRE) on the MTF-1 (metal regulatory-transcription factor-1), which induces the expression of MTs (Krizkova et al., 2016). Therefore, it might be that MTs play a more general role in the regulation of free intracellular ions instead of $\mathrm{Zn}$ ions alone.

Humans are exposed to NMs mainly through inhalation, ingestion and contact with skin or mucous membranes. In the first line of defense, tissue macrophages engulf foreign particles, and dendritic cells (DC) are the professional antigen presenters to activate adaptive immunity. To simulate the natural interactions in this study, we differentiated THP-1 cells to mature macrophage phenotype 
showing enhanced adherence and phagocytosis (Qin, 2012). Both macrophages and DCs have various pattern recognition receptors (PRRs) to sense extracellular pathogens by pathogen-associated molecular pattern (PAMP), and intracellular pathogens or stress by damage/danger-associated molecular pattern (DAMP) such as toll-like receptors (TLRs), RIG-I-like receptors (RLR) and NODlike receptors (NLRs). Based on our results, it seems that NMs are able to activate similar cellular pathways as viruses. They both induce PAMP-dependent pathways (TLR, RLR), cytokines (IFNs, TNF), and inflammasome, which is mainly responsible for the regulation and production of the proinflammatory IL-1 $\beta$ cytokine.

TLR7, which was upregulated in our study by n-Ag at 24h, usually recognizes single-stranded RNA of viruses, and regulates antiviral immunity. Downstream of TLRs, the IFN-regulatory factors (IRFs) IRF3 and IRF7 are activated, which lead to the expression of IFN $\beta$ and IFIT (interferoninduced protein with tetratricopeptide repeats) genes (Ablasser and Hornung, 2011). Secretion of IFN $\beta$ by the infected cells results in type I IFN signaling that induces hundreds of IFN-stimulated genes (ISGs) (Diamond and Farzan, 2013). In our study, especially n-Ag induced IFN-related gene expressions including IFIT1-3 and IFIT5 genes, IFI44 (IFN-induced-protein 44) and MX2, which is a IFN-induced GTP-binding protein. After cellular stress or type I IFN responses, IFIT proteins exist in great abundance within a larger IFIT1-3 complex to inhibit viral replication, and to regulate the cell apoptosis (Leavy, 2011, Pichlmair et al., 2011). Interferon-associated genes are not usually connected to NM-induced responses but McDermott et al (McDermott et al., 2011) who used computational analyses to fetch out a common "core response module" of DEGs for macrophage activation after exposure to TLR agonists, Salmonella and silica nanoparticles, had IFIT1-2 and IFI44 in their target list. NMs associated with an antigens, leads to the recognition and activation of TLRs, which might be beneficial in medicine (vaccines), but if the interactions persist in the living system, the consequences might progress into harmful chronic responses. 
Inflammasomes have a crucial role during viral infection, but is it proposed that various crystals and particles may also activate inflammasomes via lysosomal dysfunction and damagemediated mechanism (Cassel et al., 2008, Hornung et al., 2008, Palomaki et al., 2011, Weber and Schilling, 2014). To become fully active, NLRP3 needs to be primed first via toll-like receptors (TLRs) or induced via NF- $\mathrm{B}$ pathway, which is then activated by stimuli from various PAMPs and DAMPs (Jo et al., 2016). These events trigger the activation of inflammatory caspases and the maturation of IL-1 $\beta$ and IL-18 into active cytokines, leading to the initiation and enhancement of inflammation (Jo et al., 2016). In this study, our results suggest that inflammasomes are activated, since proinflammatory IL- $1 \beta$ and TNF, as well as NF- $\kappa$ B1 A gene expressions were already enhanced after 6h exposure to b-Zn, n-Zn and n-Ag (Figure 5 and Supplementary Material, Figure S3). Additionally, n-Ag induced the expression of cathepsins C, G, K, Z and V, which are serine/cysteine proteases digesting engulfed material in the lysosomes (Supplementary Material, Tables S2-S3). Yang et al (Yang et al., 2012) have found that exposure of Ag NMs in primary human monocytes may cause leakage of cathepsins from lysosomes and efflux of intracellular $\mathrm{K}^{+}$, which together induce superoxide leading to inflammasome formation.

The recognition and uptake of a foreign antigen, leads to the activation of innate immunity responses and recruitment of immune cells to the site of inflammation. In our study, at $6 \mathrm{~h}$ after the $\mathrm{NM}$ exposures, $\mathrm{b}-\mathrm{Zn}, \mathrm{n}-\mathrm{Zn}$ and $\mathrm{n}-\mathrm{Ag}$ all induced the expression of several chemokines recruiting neutrophils (CXCL8, CCL20, CCL3, CXCL2), monocytes (CCL3, CCL1, CXCL3, CXCL14), DCs (CCL1, CXCL14), lymphocytes (CCL20, CCL1) and natural killer cells (CCL1, CXCL14) to the site of inflammation (Figure 5). After engulfment of foreign antigens, mature macrophages (and DCs) enhance their antigen presentation, express several co-stimulatory molecules and travel to local lymph nodes with the help of CCR7, whose expression was also induced in our study. Naturally, these and further interactions with T- and B-cells occur in living organism, but this study with the 
THP-1 macrophages and their responses, provide insights in the initial recognition and cellular responses to NMs. 


\section{Conclusion}

Different interactions and cellular uptake of nanomaterials that have different physical properties, but are otherwise chemically similar, complicates the traditional concept of dose when it comes to nanosafety assessment. Utilizing such a set-up wherein, we investigated transcriptomic changes associated with exposure to the maximum sub-lethal dose enables characterization of the early immune signaling and material-specific adaptive responses to adverse NM exposures. In this study, $\mathrm{n}-\mathrm{TiO}_{2}$ and $\mathrm{b}-\mathrm{TiO}_{2}$ did not cause any significant changes in the cellular responses or even in the transcriptome of the differentiated THP-1 cells. Exposure to $\mathrm{n}-\mathrm{ZnO}$ and b- $\mathrm{ZnO}$, and also to $\mathrm{n}-\mathrm{Ag}$ and i-Ag enhanced the expression of metallothioneins which are responsible for the ionic homeostasis in the cells. In addition to these direct ionic effects, $\mathrm{n}-\mathrm{ZnO}$ and $\mathrm{n}-\mathrm{Ag}$ induced the expression of several innate and adaptive immunity pathways and responses in the global microarray analysis. These NMs seem to activate mostly intracellular PRRs including NLRs and TLRs, which lead to the activation of inflammasome, production of proinflammatory IL-1 $\beta$ and strong interferon response usually initiated by viruses. Although differentiated THP-1 cells were cultured alone, they were able to secrete several chemokines, which in a living organism would recruit neutrophils, monocytes, lymphocytes and NK cells to help to resolve the NM-originated danger. The in-depth understanding of these cellular and molecular mechanisms of NMs would help the development of safe nanomaterials for nanotechnology-based consumer products without harmful or even dangerous side effects. Altogether, our results strongly suggest that in addition to well described ionic effects mediated by metallothioneins, these metallic NMs are able to induce several innate and adaptive immunity associated pathways that are known to play crucial role in the immune functions. 


\section{List of abbreviations}

C, non-treated control group; CCL, CC chemokine ligand; CCR, CC chemokine receptor; CXCL, CXC chemokine ligand; Cy, cyanine dye; DEG, differentially expressed genes; dNTP, deoxynucleotide triphosphate; NM, nanomaterial; FC, fold change; GO, Gene Ontology; H\&E, hematoxylin and eosin; IL, interleukin; MIP, macrophage inflammatory protein; mRNA, messenger ribonucleic acid; PBS, phosphate buffered saline; PCR, polymerase chain reaction; RIN, RNA integrity number; RU, relative unit; STAT, signal transducer and activator of transcription; Th, T helper

\section{Availability of data and materials}

The datasets supporting the conclusion of this article are included within the article and its additional files. By request, the microarray data produced in this study is available from piia.karisola@helsinki.fi.

\section{Disclosure of interest}

The authors declare that they have no conflicts of interest. The authors alone are responsible for the content and writing of this article.

\section{Funding}

The study was supported by a grant from the Academy of Finland (decision 297885). 


\section{References}

Ablasser, A. \& Hornung, V., 2011. Where, in antiviral defense, does IFIT1 fit? Nat Immunol, 12, 588-90.

Asharani, P.V., Low Kah Mun, G., Hande, M.P. \& Valiyaveettil, S., 2009. Cytotoxicity and genotoxicity of silver nanoparticles in human cells. ACS Nano, 3, 279-90.

Cassel, S.L., Eisenbarth, S.C., Iyer, S.S., Sadler, J.J., Colegio, O.R., Tephly, L.A., Carter, A.B., Rothman, P.B., Flavell, R.A. \& Sutterwala, F.S., 2008. The Nalp3 inflammasome is essential for the development of silicosis. Proc Natl Acad Sci U S A, 105, 9035-40.

DeLoid, G.M., Cohen, J.M., Pyrgiotakis, G. \& Demokritou, P. Preparation, characterization, and in vitro dosimetry of dispersed, engineered nanomaterials. Nat Protoc, 12, 355-71.

Deng, Z.J., Liang, M., Monteiro, M., Toth, I. \& Minchin, R.F., 2011. Nanoparticle-induced unfolding of fibrinogen promotes Mac-1 receptor activation and inflammation. Nat Nanotechnol, 6, 39-44.

Diamond, M.S. \& Farzan, M., 2013. The broad-spectrum antiviral functions of IFIT and IFITM proteins. Nat Rev Immunol, 13, 46-57.

Gliga, A.R., Skoglund, S., Wallinder, I.O., Fadeel, B. \& Karlsson, H.L., 2014. Size-dependent cytotoxicity of silver nanoparticles in human lung cells: the role of cellular uptake, agglomeration and Ag release. Part Fibre Toxicol, 11, 11.

Gojova, A., Guo, B., Kota, R.S., Rutledge, J.C., Kennedy, I.M. \& Barakat, A.I., 2007. Induction of inflammation in vascular endothelial cells by metal oxide nanoparticles: effect of particle composition. Environ Health Perspect, 115, 403-9.

Hanley, C., Thurber, A., Hanna, C., Punnoose, A., Zhang, J. \& Wingett, D.G., 2009. The Influences of Cell Type and ZnO Nanoparticle Size on Immune Cell Cytotoxicity and Cytokine Induction. Nanoscale Res Lett, 4, 1409-20.

He, Z. \& Alexandridis, P., 2015. Nanoparticles in ionic liquids: interactions and organization. Phys Chem Chem Phys, 17, 18238-61.

Hornung, V., Bauernfeind, F., Halle, A., Samstad, E.O., Kono, H., Rock, K.L., Fitzgerald, K.A. \& Latz, E., 2008. Silica crystals and aluminum salts activate the NALP3 inflammasome through phagosomal destabilization. Nat Immunol, 9, 847-56.

Hsiao, I.L., Hsieh, Y.K., Wang, C.F., Chen, I.C. \& Huang, Y.J., 2015. Trojan-horse mechanism in the cellular uptake of silver nanoparticles verified by direct intra- and extracellular silver speciation analysis. Environ Sci Technol, 49, 3813-21.

Jo, E.K., Kim, J.K., Shin, D.M. \& Sasakawa, C., 2016. Molecular mechanisms regulating NLRP3 inflammasome activation. Cell Mol Immunol, 13, 148-59.

Johnson, W.E., Li, C. \& Rabinovic, A., 2007. Adjusting batch effects in microarray expression data using empirical Bayes methods. Biostatistics, 8, 118-27.

Kallio, M.A., Tuimala, J.T., Hupponen, T., Klemela, P., Gentile, M., Scheinin, I., Koski, M., Kaki, J. \& Korpelainen, E.I., 2011. Chipster: user-friendly analysis software for microarray and other high-throughput data. BMC Genomics, 12, 507.

Kimura, T. \& Kambe, T., 2016. The Functions of Metallothionein and ZIP and ZnT Transporters: An Overview and Perspective. Int J Mol Sci, 17, 336.

Krizkova, S., Kepinska, M., Emri, G., Rodrigo, M.A., Tmejova, K., Nerudova, D., Kizek, R. \& Adam, V., 2016. Microarray analysis of metallothioneins in human diseases--A review. J Pharm Biomed Anal, 117, 464-73.

Kruszewski, M., Brzoska, K., Brunborg, G., Asare, N., Dobrzynska, M., Dusinska, M., Fjellsbo, L.M., Georgantzopoulou, A., Gromadzka-Ostrowska, J., Gutleb, A.C., Lankoff, A., Magdolenova, 
Z., Pran, E.R., Rinna, A., Instanes, C., Sandberg, W.J., Schwarze, P., Stepkowski, T., Wojewodzka, M. \& Refsnes, M., 2011. Toxicity of Silver Nanomaterials in Higher Eukaryotes. Advances in Molecular Toxicology, Vol 5, 5, 179-218.

Leavy, O., 2011. Vaccines: Dual TLR hit for vaccine success. Nat Rev Immunol, 11, 234-5.

Lopes, S., Pinheiro, C., Soares, A.M. \& Loureiro, S., 2016. Joint toxicity prediction of nanoparticles and ionic counterparts: Simulating toxicity under a fate scenario. J Hazard Mater, 320, 1-9.

Ma, H., Williams, P.L. \& Diamond, S.A., 2013. Ecotoxicity of manufactured ZnO nanoparticles--a review. Environ Pollut, 172, 76-85.

Mcdermott, J.E., Archuleta, M., Thrall, B.D., Adkins, J.N. \& Waters, K.M., 2011. Controlling the response: predictive modeling of a highly central, pathogen-targeted core response module in macrophage activation. PLoS One, 6, e14673.

Nowack, B., Krug, H.F. \& Height, M., 2011. 120 years of nanosilver history: implications for policy makers. Environ Sci Technol, 45, 1177-83.

Oliveros, J.C., 2007-2015. Venny. An interactive tool for comparing lists with Venn's diagrams. http://bioinfogp.cnb.csic.es/tools/venny/index.html.

Palomaki, J., Valimaki, E., Sund, J., Vippola, M., Clausen, P.A., Jensen, K.A., Savolainen, K., Matikainen, S. \& Alenius, H., 2011. Long, needle-like carbon nanotubes and asbestos activate the NLRP3 inflammasome through a similar mechanism. ACS Nano, 5, 6861-70.

Pichlmair, A., Lassnig, C., Eberle, C.A., Gorna, M.W., Baumann, C.L., Burkard, T.R., Burckstummer, T., Stefanovic, A., Krieger, S., Bennett, K.L., Rulicke, T., Weber, F., Colinge, J., Muller, M. \& Superti-Furga, G., 2011. IFIT1 is an antiviral protein that recognizes 5'-triphosphate RNA. Nat Immunol, 12, 624-30.

Qin, Z., 2012. The use of THP-1 cells as a model for mimicking the function and regulation of monocytes and macrophages in the vasculature. Atherosclerosis, 221, 2-11.

Ritchie, M.E., Phipson, B., Wu, D., Hu, Y., Law, C.W., Shi, W. \& Smyth, G.K., 2015. limma powers differential expression analyses for RNA-sequencing and microarray studies. Nucleic Acids Res, 43, e47.

Roy, R., Das, M. \& Dwivedi, P.D., 2015. Toxicological mode of action of ZnO nanoparticles: Impact on immune cells. Mol Immunol, 63, 184-92.

Sharma, V.K., Siskova, K.M., Zboril, R. \& Gardea-Torresdey, J.L., 2014. Organic-coated silver nanoparticles in biological and environmental conditions: fate, stability and toxicity. Adv Colloid Interface Sci, 204, 15-34.

Shi, H., Magaye, R., Castranova, V. \& Zhao, J., 2013. Titanium dioxide nanoparticles: a review of current toxicological data. Part Fibre Toxicol, 10, 15.

Tuli, H.S., Kashyap, D., Bedi, S.K., Kumar, P., Kumar, G. \& Sandhu, S.S., 2015. Molecular aspects of metal oxide nanoparticle (MO-NPs) mediated pharmacological effects. Life Sci, 143, 71-9.

Tuomela, S., Autio, R., Buerki-Thurnherr, T., Arslan, O., Kunzmann, A., Andersson-Willman, B., Wick, P., Mathur, S., Scheynius, A., Krug, H.F., Fadeel, B. \& Lahesmaa, R., 2013. Gene expression profiling of immune-competent human cells exposed to engineered zinc oxide or titanium dioxide nanoparticles. PLoS One, 8, e68415.

Tyanova, S., Temu, T., Sinitcyn, P., Carlson, A., Hein, M.Y., Geiger, T., Mann, M. \& Cox, J., 2016. The Perseus computational platform for comprehensive analysis of (prote)omics data. Nat Methods, 13, 731-40.

Utembe, W., Potgieter, K., Stefaniak, A.B. \& Gulumian, M., 2015. Dissolution and biodurability: Important parameters needed for risk assessment of nanomaterials. Part Fibre Toxicol, 12, 11. 
Weber, K. \& Schilling, J.D., 2014. Lysosomes integrate metabolic-inflammatory cross-talk in primary macrophage inflammasome activation. J Biol Chem, 289, 9158-71.

Yang, E.J., Kim, S., Kim, J.S. \& Choi, I.H., 2012. Inflammasome formation and IL-1beta release by human blood monocytes in response to silver nanoparticles. Biomaterials, 33, 6858-67.

Zhang, X.F., Shen, W. \& Gurunathan, S., 2016. Silver Nanoparticle-Mediated Cellular Responses in Various Cell Lines: An in Vitro Model. International Journal of Molecular Sciences, 17. 
Appendices

Supplementary Material:

-Methods

-Supplementary Figures S1-S6

-Suplementary Tables S1-S3 


\section{Supplementary Material:}

\section{Nanosized zinc oxide and silver, but not titanium dioxide, induce innate and adaptive immunity and antiviral response in differentiated THP-1 cells}

Wing-Lam Poon ${ }^{11}$ Harri Alenius ${ }^{2,3}$, Joseph Ndika ${ }^{2}$, Vittorio Fortino ${ }^{4}$, Vesa Kolhinen ${ }^{5}$, Arūnas Meščeriakovas ${ }^{6}$, Mingfu Wang $^{1}$, Dario Greco ${ }^{4,7}$, Anna Lähde ${ }^{6}$, Jorma Jokiniemi $^{6}$, Jetty Chung-Yung Lee $^{1}$, Hani El-Nezami ${ }^{1,8 *}$, Piia Karisola ${ }^{2 *}$

${ }^{1}$ School of Biological Sciences, University of Hong Kong, Pokfulam Road, Hong Kong

${ }^{2}$ Department of Bacteriology and Immunology, University of Helsinki, Haartmaninkatu 3, 00290 Helsinki, Finland

${ }^{3}$ Institute of Environmental Medicine (IMM), Karolinska Institutet, Stockholm 171 77, Sweden

${ }^{4}$ Institute of Biotechnology, University of Helsinki, Helsinki 00100, Finland

${ }^{5}$ Finnish Environment Institute (SYKE), Mechelininkatu 34a, 00260 Helsinki, Finland

${ }^{6}$ Department of Environmental Science, University of Eastern Finland, 70211 Kuopio, Finland

${ }^{7}$ Faculty of Medicine and Life Sciences, University of Tampere, P.O. Box 100, University of

Tampere, Finland

${ }^{8}$ Institute of Public Health and Clinical Nutrition, School of Medicine, University of Eastern Finland, P.O. Box 1627, 70211 Kuopio, Finland

*Address correspondence to Piia.Karisola@Helsinki.fi or to elnezami@hku.hk 


\section{TABLE OF CONTENTS}

\section{SUPPLEMENTARY METHODS}

Cell Culture $\quad 3$

Dynamic Light Scattering (DLS) and viscosimetry 3

Dosimetry modelling 4

MTT assay for Cell Viability and Metabolic Activity 4

Cytokine Expressions $\quad 5$

$\begin{array}{lc}\text { RT-PCR Validation } & 6\end{array}$

$\begin{array}{ll}\text { References } & 6\end{array}$

SUPPLEMENTARY FIGURES Page\#

$\begin{array}{lr}\text { Supplementary Figure S1 } & 7\end{array}$

$\begin{array}{lr}\text { Supplementary Figure S2 } & 8\end{array}$

$\begin{array}{ll}\text { Supplementary Figure S3 } & 9\end{array}$

$\begin{array}{lr}\text { Supplementary Figure S4 } & 10\end{array}$

$\begin{array}{ll}\text { Supplementary Figure S5 } & 11\end{array}$

$\begin{array}{ll}\text { Supplementary Figure S6 } & 12\end{array}$

SUPPLEMENTARY TABLES $\quad$ Page\#

$\begin{array}{lc}\text { Supplementary Table S1 } & 13\end{array}$

$\begin{array}{ll}\text { Supplementary Table S2 } & 13\end{array}$

$\begin{array}{ll}\text { Supplementary Table S3 } & 13\end{array}$ 


\section{SUPPLEMENTARY METHODS}

\section{Cell Culture}

All cell lines were purchased from American Type Culture Collection (ATCC, Rockville, MD, USA). RPMI 1640, fetal bovine serum (FBS), GlutaMAX ${ }^{\mathrm{TM}}$ supplement, 4-(2-hydroxyethyl)-1piperazineethanesulfonic acid (HEPES), and penicillin-streptomycin (PEST) were purchased from Gibco, Life Technologies (Grand Island, NY, USA). Mercaptoethanol (2-ME) was obtained from Sigma-Aldrich (Schnelldoff, Germany). Cells were centrifuged with Eppendorf Centrifuge 5417R, 5415D (Hamburg, Germany) and Beckman Centrifuge GS-15R (Beckman Coulter, IN). Cell morphology examination and cell calculations were done using Olympus CKX41 light microscope (Hamburg, Germany).

THP-1 cells are human leukemia monocytic cells that grow in suspension. It can be differentiated into adherent macrophage-like cells by phorbol-12-myristate-13-acetate (PMA). Cells were grown in RPMI supplemented with 10\% FBS, 1\% GlutaMAX, 1\% HEPES, 0.05 mM 2-ME, and $1 \%$ PEST at $37^{\circ} \mathrm{C}$ with a humidified atmosphere of $5 \% \mathrm{CO}_{2}$. Suspension cell cultures (35 ml) was maintained in T75 flasks with cell density between 0.2 to $1.5 \times 10^{6}$ cells $/ \mathrm{mL}$. Before treatment with NMs, cells were grown in medium with $50 \mathrm{nM}$ PMA for $48 \mathrm{~h}$ to trigger macrophage differentiation. This differentiation medium (with PMA) was refreshed once after the first $24 \mathrm{~h}$. Cells passages used were between 9 and 20.

\section{Dynamic Light Scattering (DLS) and viscosimetry}

The hydrodynamic particle size and zeta potential of the freshly made suspensions were measured using electrophoretic mobility analysis (ZetaSizer ZS DLS, Malvern Instruments) (Table S1). The measurements were carried out in triplicates and the average value was calculated based on the measurements. The calibration of the equipment was done using spherical latex particles suspended 
in ion-exchanged water. The zeta potential was calibrated with calibration liquid purchased from the Malvern Instruments.

The viscosity of the suspensions was determined by continuous reading of percent full scale [\%], viscosity [cps, centipoise] and shear stress [SS, dynes $\left./ \mathrm{cm}^{2}\right]$ with the Brookfield Digital Viscometer, Model DV-II, with the spindle CP-40 attached to the viscometer. All readings were below $10 \%$ of the full-scale ranges.

\section{Dosimetry modelling}

The particle and agglomerate properties (sizes) and their distribution were studied by EM, DLS and viscometer, and their actual dosages were modelled by the method described by DeLoid et al. 2017 (Figure S1).

\section{MTT assay for Cell Viability and Metabolic Activity}

Cell viability after $24 \mathrm{~h}$ exposure was probed by the MTT assay. 3-[4,5-dimethylthiazol-2yl]-2,5diphenyltetrazolium bromide or MTT (Sigma) is reduced into purple formazan crystals in metabolically active cells. THP-1 cells were seeded in 96-well plate at a density of 1 x $10^{5}$ cells/well in $200 \mu 1$. After 48h PMA-induced macrophage differentiation, the cells were treated with $0.1-100$ $\mu \mathrm{g} / \mathrm{ml}$ of each nanoparticle. Cell-free controls were included. DMSO (50\%) was used as positive control. Three replicates were used for each concentration. After $22 \mathrm{~h}$ of exposure, $100 \mu \mathrm{l}$ of the supernatant was collected for the LDH assay and then $10 \mu$ lof stock MTT solution $(5 \mathrm{mg} / \mathrm{mL}$ in PBS) was added to each well followed by $2 \mathrm{~h}$ incubation. Afterwards, the plate was centrifuged at $300 \mathrm{xg}$ for 1 minute and then, the supernatant was carefully pipetted away so that the treatment wells and corresponding cell-free control wells would retain similar amount of particles. Finally, $100 \mu 1$ of DMSO was added to dissolve the purple formazan crystals formed intracellularly and the plate was shaken for 30 minutes to allow full solubilisation. The absorbance was measured at $595 \mathrm{~nm}$ on a plate 
reader (Thermo Fisher Multiskan GO) with reference wavelength set as $655 \mathrm{~nm}$ to remove most of the physical interference. The absorbance of cell-free controls (particle and MTT) was subtracted to correct for the acellular particle interference: (i) cell-free catalysis of dye reduction by particles and (ii) physical interference with absorbance reading (Park et al., 2009, Kong et al., 2011, Keene et al., 2014) The results are expressed as \% cell viability calculated as:

$$
\% \text { cell viability }=\frac{(\text { absorbance of treated cells }- \text { absorbance of positive control })}{(\text { absorbance of untreated cells }- \text { absorbance of positive control })} \times 100 \%
$$

To study the role of extracellularly released ions, additional MTT experiments were done as previously described (Gliga et al., 2014). Shortly, n-ZnO, b-ZnO and n-Ag dispersions (30 and 100 $\mu \mathrm{g} / \mathrm{ml}$ ) were either incubated alone in the complete medium, or with differentiated THP-1 macrophages on 96 -well plate for $24 \mathrm{~h}$ at $37^{\circ} \mathrm{C}$ and $5 \%$ of $\mathrm{CO}_{2}$. After $24 \mathrm{~h}$, the total effect of particles was studied by measuring the viability of the treated cells by the MTT assay. The cell-free suspensions were transferred to $1.5 \mathrm{ml}$ micro-centrifuge tubes, which were centrifuged to sediment the NM particles at $20,800 \times \mathrm{g}($ or $14,000 \mathrm{rpm})$ at $4^{\circ} \mathrm{C}$. After the first $10 \mathrm{~min}$ centrifugation, supernatants were transferred to a new $1.5 \mathrm{ml}$ tube and centrifuged again for $50 \mathrm{~min}$. Afterwards, the supernatants were used to treat another set of differentiated THP-1 macrophages. After $24 \mathrm{~h}$, the effect of centrifuged supernatants (extracellularly released ions) on cell viability was measured by the MTT assay.

\section{Cytokine Expressions}

The cells were seeded in 6-well plate at a density of $1.8-2 \times 10^{6}$ cells/well in $2 \mathrm{ml}$. After 48 hours of PMA-induced macrophage differentiation, the cells were exposed to $1-100 \mu \mathrm{g} / \mathrm{ml}$ of each particle and compared to untreated cells later. Cells treated with 10 , or $100 \mathrm{ng} / \mathrm{ml}$ bacterial lipopolysaccharide (LPS) from Escherichia coli serotype O111:B4 (Sigma-Aldrich, US) were used as positive controls. Triplicates were used for each concentration. After $6 \mathrm{~h}$ and $24 \mathrm{~h}$ of exposure, the cells were rinsed with PBS twice to remove dead cells and particles. Then, the washed cells were lysed by resuspensing cells into $350 \mu \mathrm{l}$ of RL buffer for RNA purification. 
Total RNA purification (including miRNA) was carried out using the Norgen's total RNA purification plus kit according to the manufacturer's instructions (Norgen Biotek Corp., Thorold, ON, Canada). Briefly, the cells were lysed in buffer RL (Norgen kit), and cell lysates were purified with the gDNA removal column followed by the RNA purification column. The concentration of RNA was measured with NanoDrop (NanoDrop Techniques INC, Wilminton, Delaware, USA), and complementary-DNA (cDNA) was synthesized from 500 ng of RNA by PCR. IL-1 $\beta$, TNF and IL-6 response units were studied with real-time PCR (TaqMan, Applied Biosystems, Foster City, USA) and normalized to $18 \mathrm{~S}$ housekeeping gene. PrimeScript ${ }^{\mathrm{TM}}$ RT Master Mix (TaKaRa), Premix Ex Taq $^{\mathrm{TM}}$ (Probe qPCR) (TaKaRa), and primers and probes for TaqMan (Applied Biosystems) were used.

PCR for cDNA synthesis was carried out at $37^{\circ} \mathrm{C}$ for 15 minutes (reverse transcription), followed by $85^{\circ} \mathrm{C}$ for 5 seconds (heat inactivation of reverse transcriptase). Real-time PCR (ABI StepOnePlus) was carried out with 3 stages: polymerase activation at $95^{\circ} \mathrm{C}$ for 20 seconds, followed by 40 cycles of melting at $95^{\circ} \mathrm{C}$ for 1 seconds and annealing/extension at $60^{\circ} \mathrm{C}$ for 20 seconds.

\section{RT-PCR Validation}

THP-1 cells were exposed to $\mathrm{n} / \mathrm{b}-\mathrm{TiO}_{2}(100 \mu \mathrm{g} / \mathrm{ml}), \mathrm{n} / \mathrm{b}-\mathrm{ZnO}$ and $\mathrm{n}-\mathrm{Ag}(10 \mu \mathrm{g} / \mathrm{ml})$, and $\mathrm{i}-\mathrm{Ag}(1 \mu \mathrm{g} / \mathrm{ml})$ for $6 \mathrm{~h}$ and $24 \mathrm{~h}$, and total RNA was extracted as explained above. The expression levels of MT1F, CXCL8 and CCL20 were validated by SYBR Green RT-PCR and normalized to RPL37a housekeeping gene. Results were expressed as the mean of triplicates \pm SD. Statistical significance was calculated by one-way ANOVA using GraphPad Prism (version 6) $(* * \mathrm{P}<0.01$, *** $\mathrm{P}<0.001$, $* * * * \mathrm{P}<0.0001)$

\section{References}

DeLoid, G.M., Cohen, J.M., Pyrgiotakis, G. \& Demokritou, P., 2017. Preparation, characterization, and in vitro dosimetry of dispersed, engineered nanomaterials. Nat Protoc, 12, 355-71. 
Gliga, A.R., Skoglund, S., Wallinder, I.O., Fadeel, B. \& Karlsson, H.L. 2014. Size-dependent cytotoxicity of silver nanoparticles in human lung cells: the role of cellular uptake, agglomeration and Ag release. Part Fibre Toxicol. 11, 11.

Keene, A.M., Bancos, S. \& Tyner, K.M., 2014. Handbook of Nanotoxicology, Nanomedicine and Stem Cell Use in Toxicology: John Wiley \& Sons, Ltd.

Kong, B., Seog, J.H., Graham, L.M. \& Lee, S.B., 2011. Experimental considerations on the cytotoxicity of nanoparticles. Nanomedicine (Lond), 6, 929-41.

Park, M.V., Annema, W., Salvati, A., Lesniak, A., Elsaesser, A., Barnes, C., Mckerr, G., Howard, C.V., Lynch, I., Dawson, K.A., Piersma, A.H. \& De Jong, W.H., 2009. In vitro developmental toxicity test detects inhibition of stem cell differentiation by silica nanoparticles. Toxicol Appl Pharmacol, 240, 108-16. 


\section{SUPPLEMENTARY FIGURES}

(A)
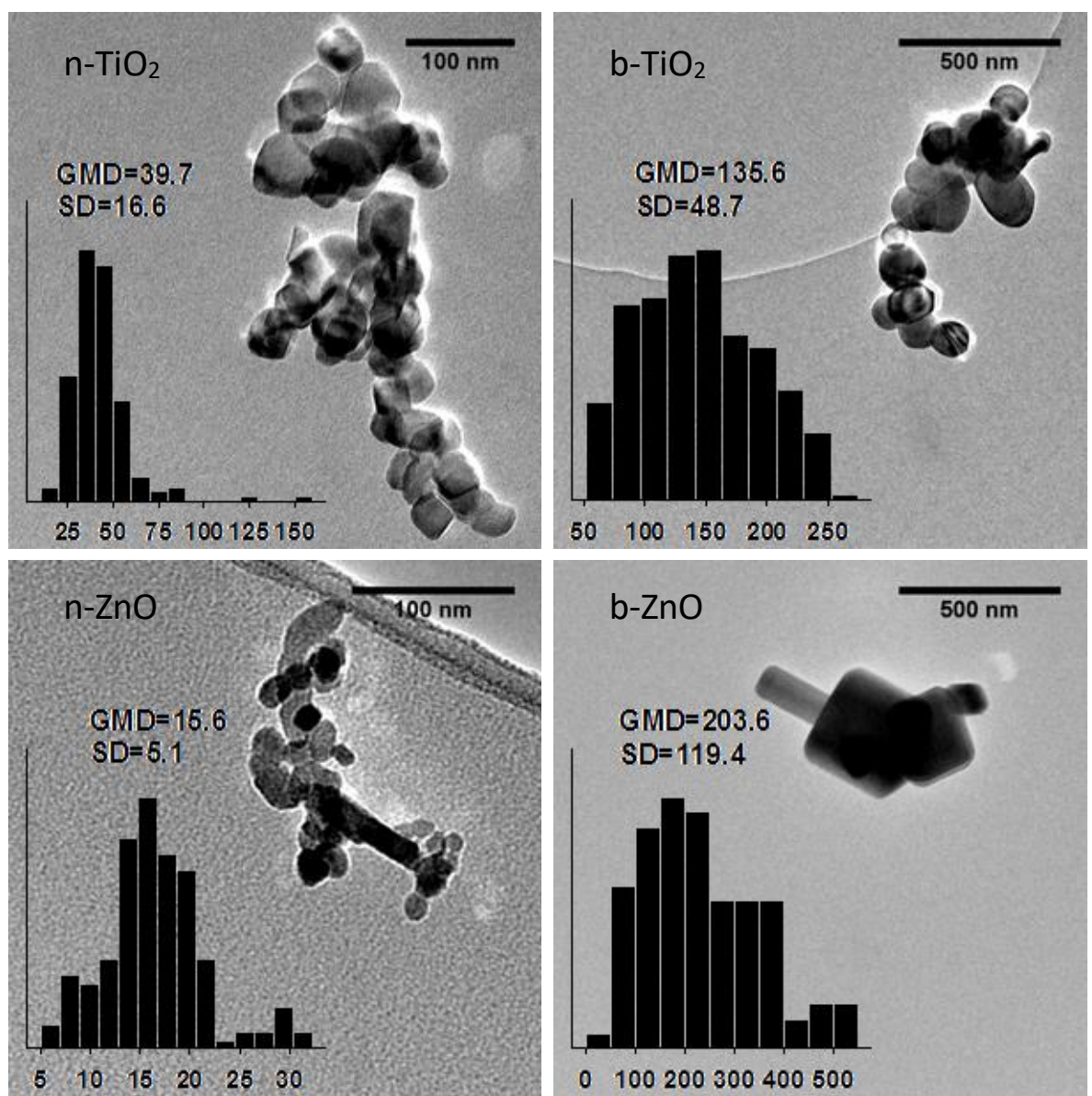

(B)

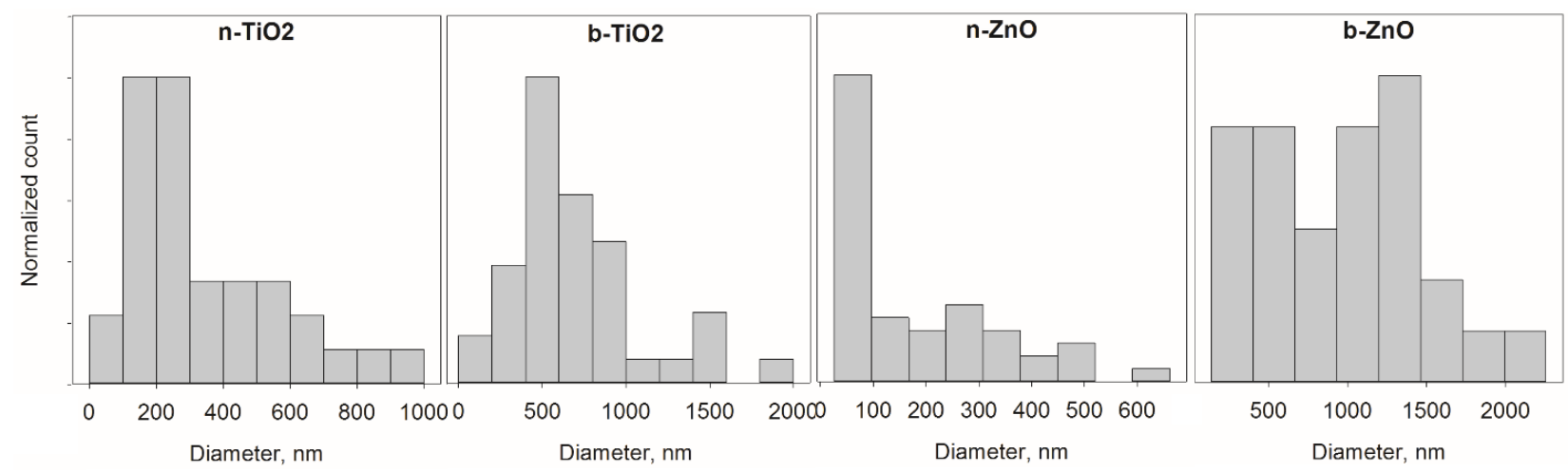

Supplementary Figure S1. Transmission electron microscopy (TEM) pictures of the particles. (A) The shape and distribution of nanosized $\mathrm{TiO}_{2}$ and $\mathrm{ZnO}$ particles, and their distribution are shown on the left-hand side figures, whereas the primary bulk-sized $\mathrm{TiO}_{2}$ and $\mathrm{ZnO}$ are accordingly shown on the right. (B) Size distributions of the $\mathrm{n} / \mathrm{b}-\mathrm{TiO}_{2}$ and $\mathrm{n} / \mathrm{b}-\mathrm{ZnO}$ agglomerates. 
(A)
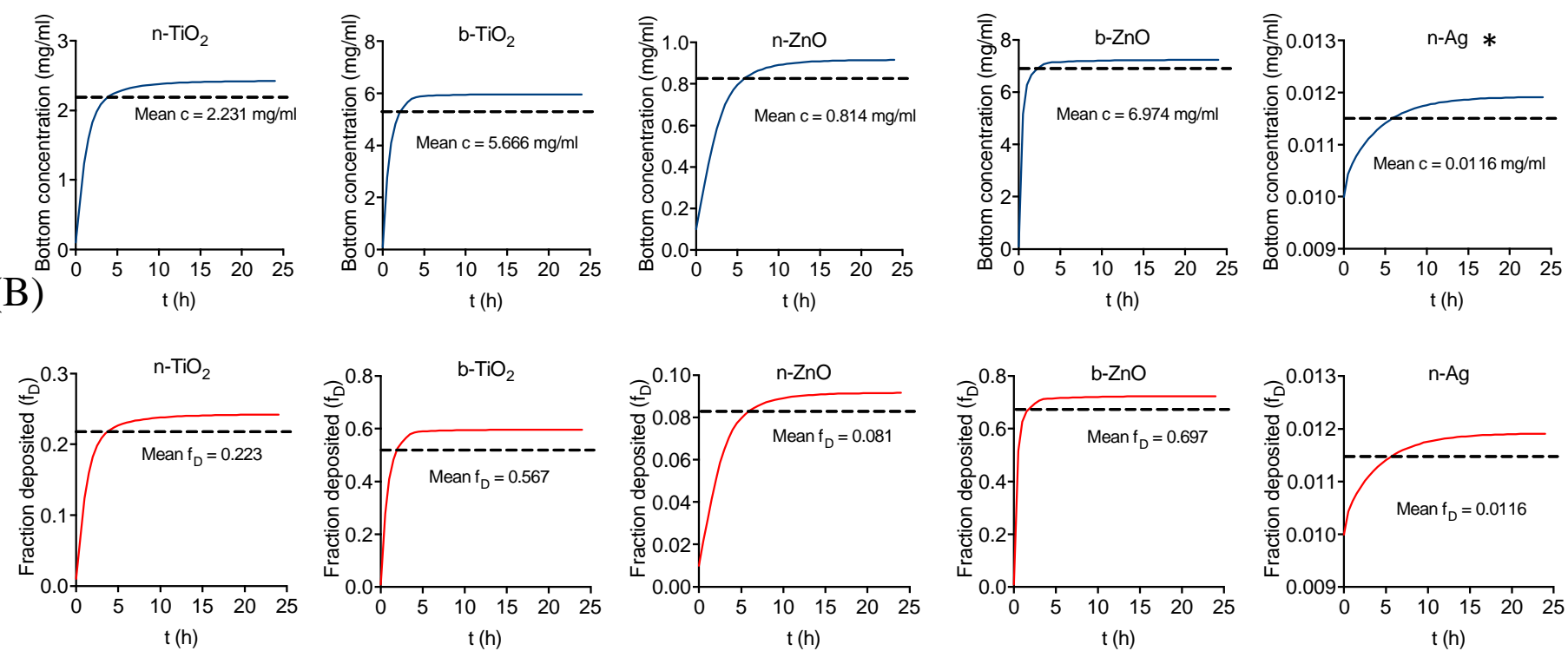

Supplementary Figure S2. Fate and Transport modelling results. (A) Well-bottom concentration of different nanoparticles over time of simulation (24h). (B) Fraction of nanoparticles deposited over time of simulation. $f_{\mathrm{D}}$, fraction deposited. ${ }^{*}$ The average agglomerate size of $\mathrm{n}-\mathrm{Ag}$ obtained from DLS $(100 \%)$ was used as an input information for dosimetry modelling due to the technical difficulties in TEM characterization. 
IL-1 $\beta$ (6h)

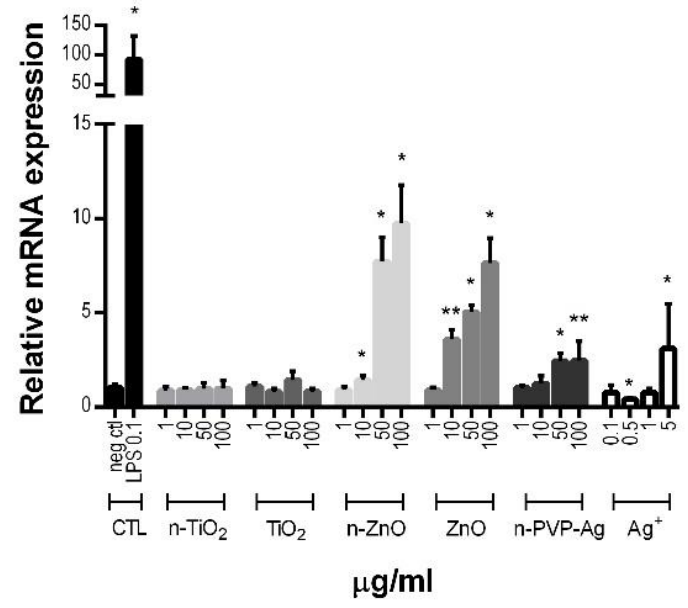

IL-1 $\beta$ (24h)

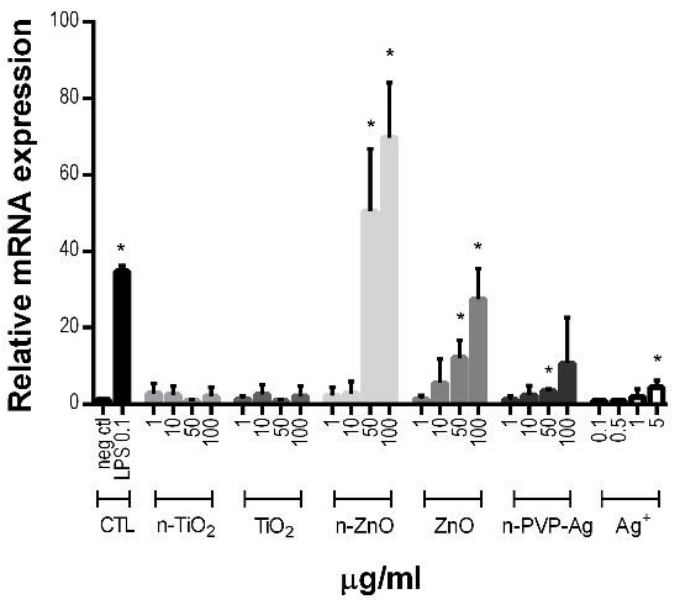

TNF (6h)

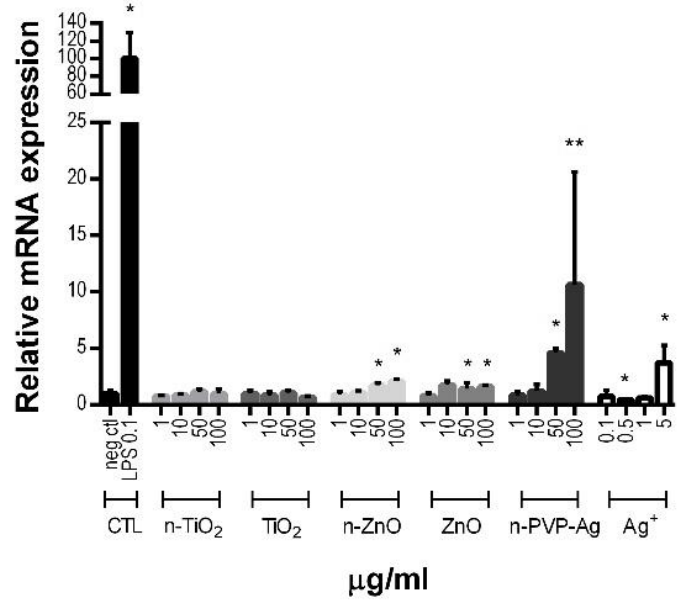

TNF (24h)

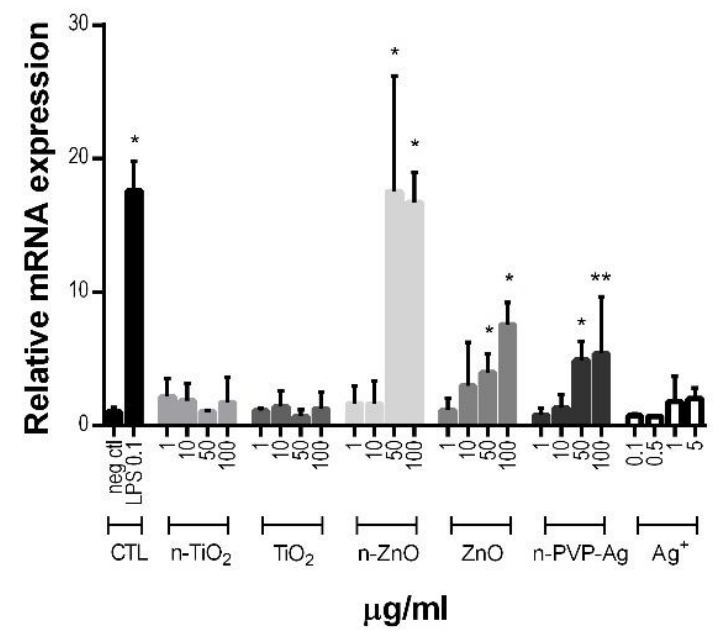


Supplementary Figure S3. The expression of proinflammatory cytokines IL-1ß and TNF in differentiated THP-1 cells at $6 \mathrm{~h}$ and $24 \mathrm{~h}$ after exposure of NMs. Expression levels were determined by RT-PCR (TaqMan) and normalized to $18 \mathrm{~S}$ housekeeping gene. Results are shown as relative expression as mean \pm SD from two independent experiments. Statistical significance indicated by $* \mathrm{P}<0.05, * * \mathrm{P}<0.01$ versus control cells determined by Mann-Whitney t-test.
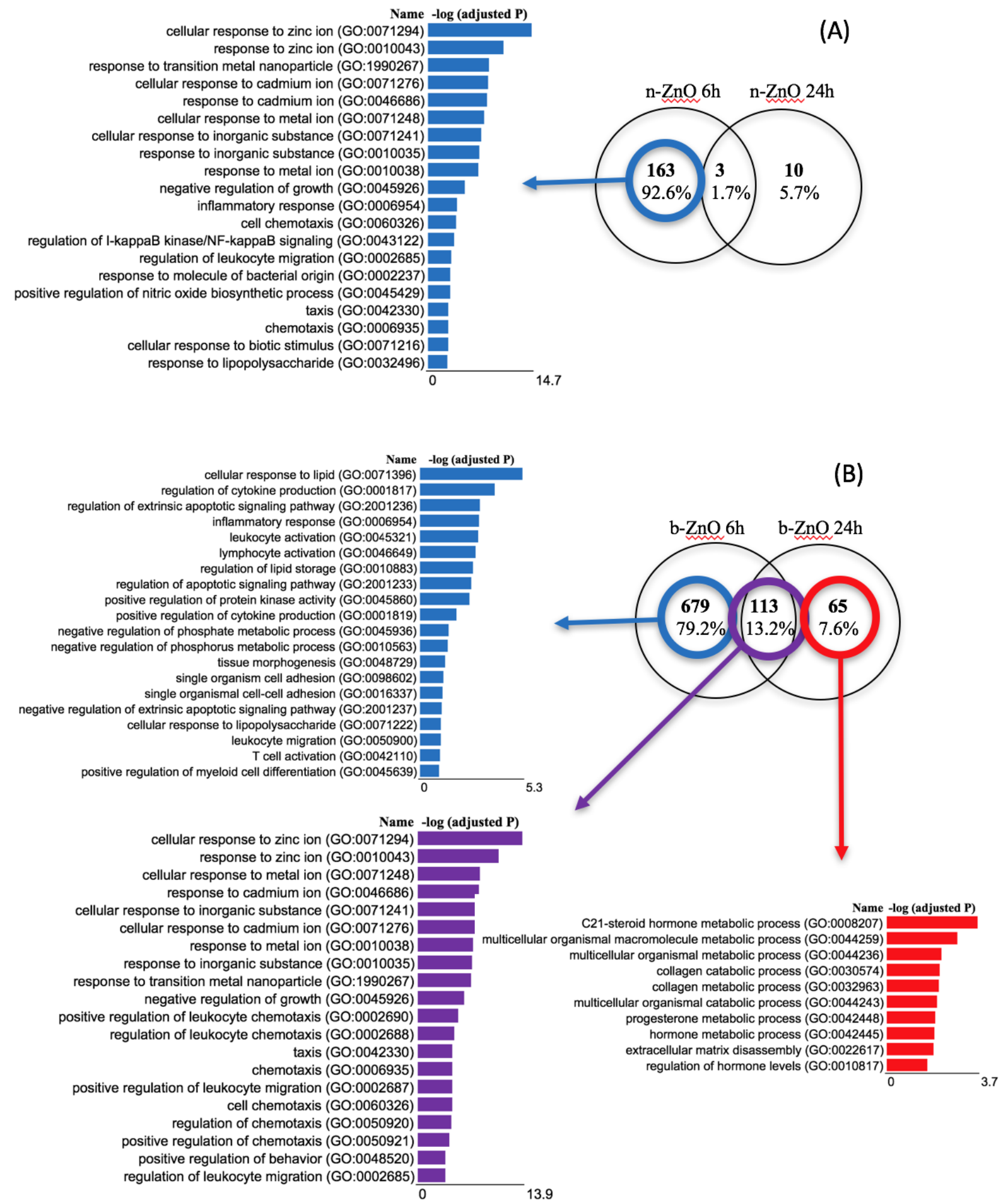
Supplementary Figure S4. Venn diagram of DEGs and related GO Biological pathways of nZnO and b-ZnO. Venn diagram demonstrates differentially up- and down-regulated genes (post hoc adj. $\mathrm{P}<0.05$, linear $\mathrm{FC}>|1.5|$ ) when (A) $\mathrm{n}-\mathrm{ZnO}$ and (B) b-ZnO particle inductions are compared at $6 \mathrm{~h}$ and at $24 \mathrm{~h}$ time points. The genes specific for $\mathrm{n}-\mathrm{ZnO}$ and $\mathrm{b}-\mathrm{ZnO}$ at both time points, and the 113 genes which were common for $\mathrm{b}-\mathrm{Zn}$ at both time points, were related to released ions, whereas the 65 genes specific for $\mathrm{b}-\mathrm{ZnO}$ alone at $24 \mathrm{~h}$ were related to hormone metabolism and collagens. Only the pathways, which had adjusted p-value less than 0.01 in the Enrichr pathway analysis program, are shown in this figure. 

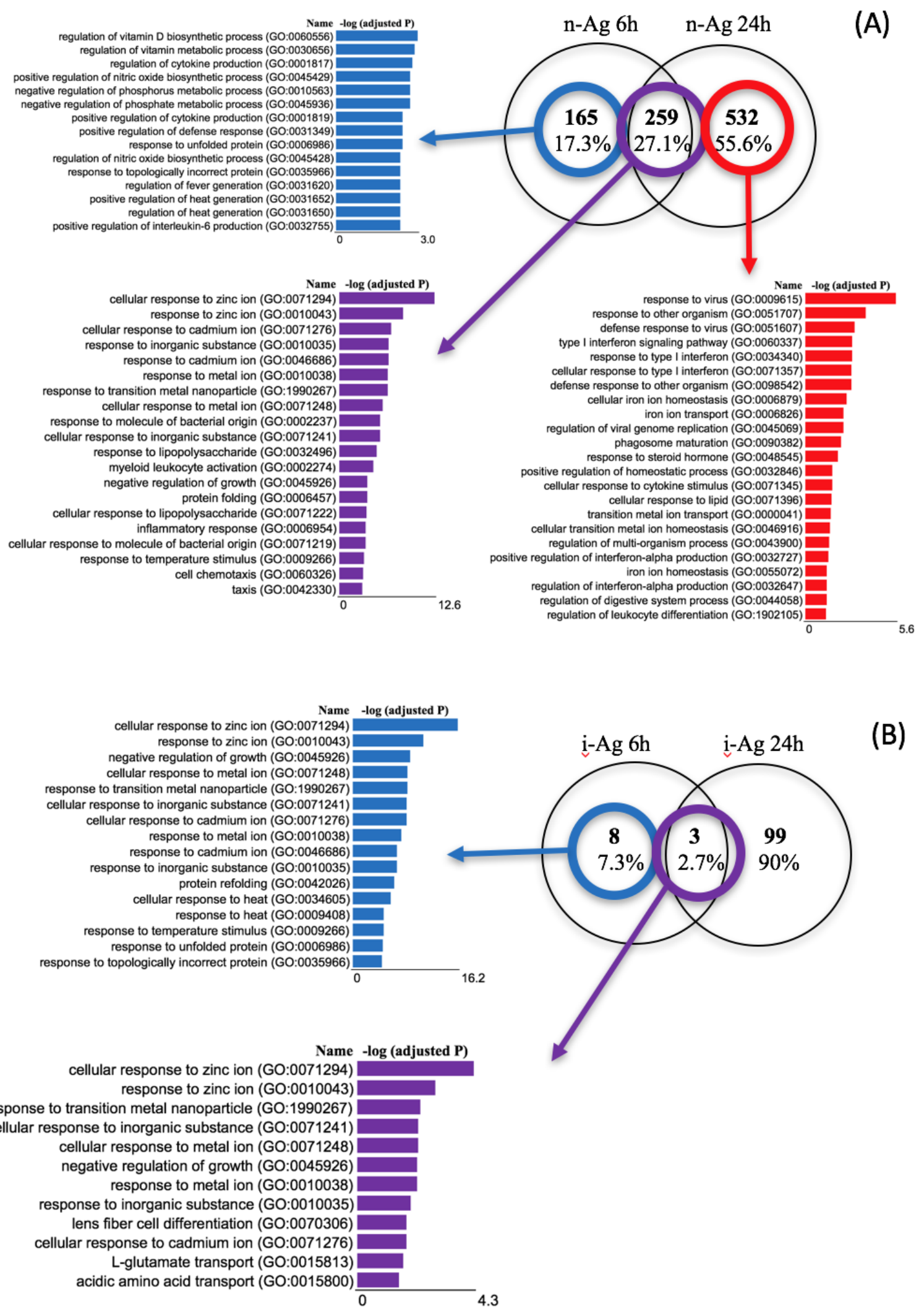

(B)

Supplementary Figure S5. Venn diagram of DEGs and related GO Biological pathways of nAg and i-Ag. Venn diagram demonstrates differentially up- and down-regulated genes (post hoc adj. $\mathrm{P}<0.05$, linear $\mathrm{FC}>|1.5|$ ) when (A) $\mathrm{n}-\mathrm{Ag}$ and (B) $\mathrm{i}-\mathrm{Ag}$ particles are compared to themselves at $6 \mathrm{~h}$ and at $24 \mathrm{~h}$ time points. All $\mathrm{i}-\mathrm{Ag}$ DEGs and common DEGs for $\mathrm{n}-\mathrm{Ag}$ at both time points were related to ionic effects. At $6 \mathrm{~h}, \mathrm{n}-\mathrm{Ag}$ caused inflammatory responses, regulated cytokine production, induced 
fever and biosynthetic pathways, and at $24 \mathrm{~h} n-\mathrm{Ag}$ was involved in the viral responses and homeostatic responses.

(A)

b-Zn at $6 \mathrm{~h}$ (443 genes)

12345678910

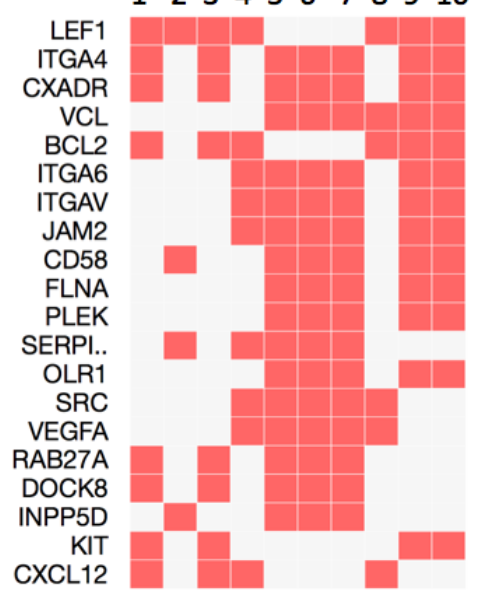

1. Lymphocyte activation

2. Regulation of cytokine production

3. Leukocyte activation

4. Regulation of cell adhesion

5. Coagulation

6. Blood coagulation

7. Hemostasis

8. Tissue morphogenesis

9. Single organism cell adhesion

10. Single organismal cell-cell adhesion

(B)

$$
\text { b-Zn at } 24 \mathrm{~h} \text { ( } 78 \text { genes) }
$$

12345678910

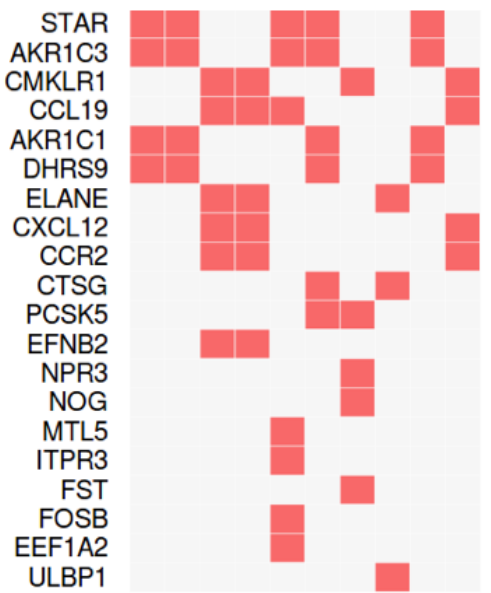

1. Progesterone metabolic process

2. C21-steroid hormone metabolic process

3. Regulation of chemotaxis

4. Regulation of behavior

5. Response to inorganic substance

6. Hormone metabolic process

7. Skeletal system development

8. Leukocyte mediated cytotoxicity

9. Cellular ketone metabolic process

10. Positive regulation of leukocyte chemotaxis
(C) b-Zn and n-Ag at $6 \mathrm{~h}$ (183 genes)

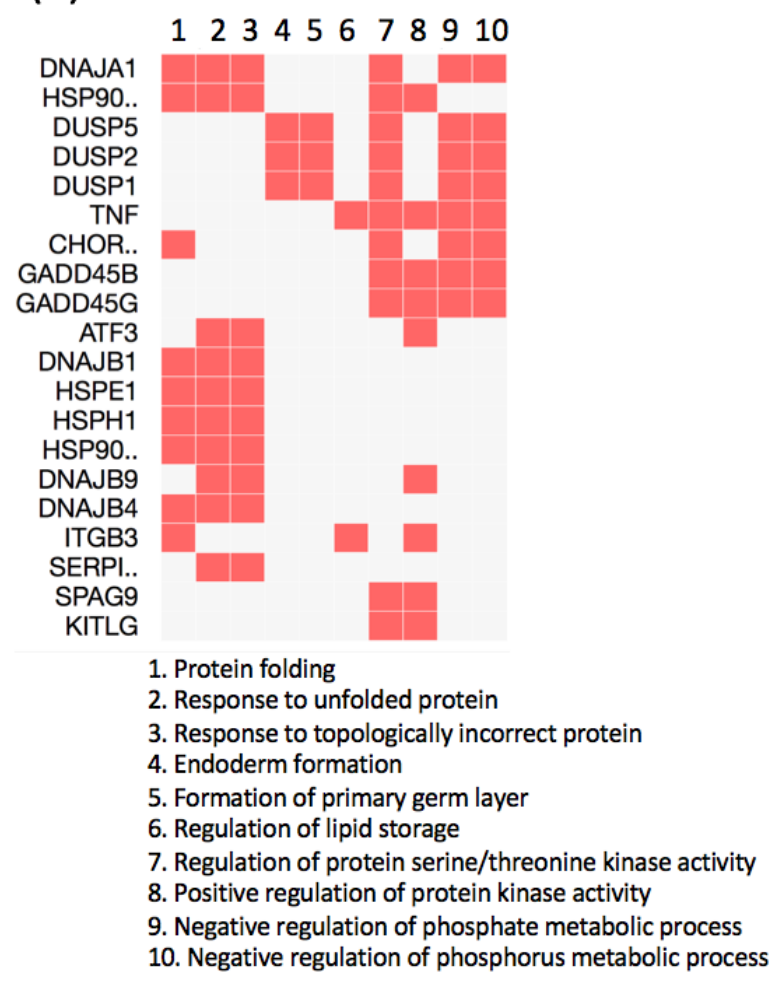

(D)

i-Ag at $24 \mathrm{~h}$ (62 genes)
$\begin{array}{llllllllll}2 & 2 & 4 & 6 & 7 & 8 & 9\end{array}$

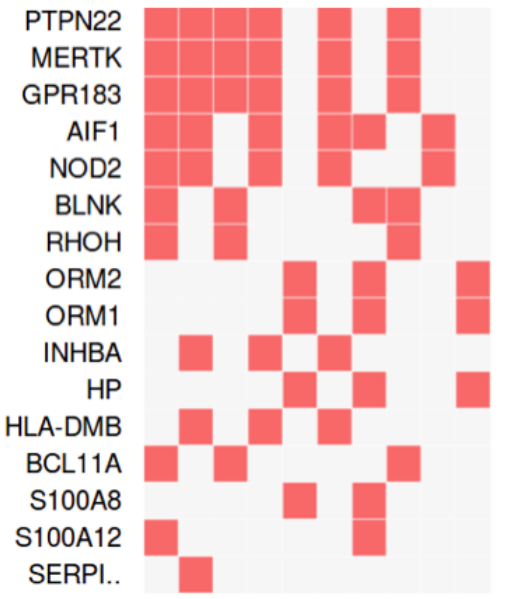

1. Leukocyte activation

2. Regulation of cell activation

3. Lymphocyte differentiation

4. Regulation of cell activation

5. Acute inflammatory response

6. Regulation of lymphocyte activation

7. Inflammatory response

8. Leukocyte differentiation

9. Microglial cell activation

10. Acute-phase response

Supplementary Figure S6. Involvement of DEGs on GO pathways. Clustergram of the top ten GO pathways with up to 20 most significant input genes revealed specific gene clusters for (A) b- 
$\mathrm{ZnO}$ including blood coagulation and leukocyte activation at $6 \mathrm{~h}$, and (B) hormonal processes and cytotoxicity at $24 \mathrm{~h}$. At $6 \mathrm{~h}(\mathrm{C}) \mathrm{b}-\mathrm{ZnO}$ and $\mathrm{n}-\mathrm{Ag}$ shared the responses to unfolded proteins, and i-Ag formed clusters for leukocyte activation and inflammation at $24 \mathrm{~h}$.

\section{SUPPLEMENTARY TABLES}

\section{Supplementary Table S1.}

\begin{tabular}{|c|c|c|c|c|c|c|c|}
\hline & solvent & n-TiO2* & b-TiO2 & $\mathrm{n}-\mathrm{ZnO} * *$ & $\mathrm{~b}-\mathrm{ZnO} * * *$ & n-PVP-Ag & Method \\
\hline \multicolumn{8}{|l|}{ Particle primary size [nm] } \\
\hline \multicolumn{8}{|l|}{ In cRPMI } \\
\hline Hydrodynamic size [nm] & 21.01 & $642 \pm 18.04$ & $544.5 \pm 8.809$ & $377.8 \pm 5.326$ & $679.6 \pm 27.27$ & $86.43 \pm 0.769$ & DLS \\
\hline Polydispersity index & 0.365 & $0.270 \pm 0.22$ & $0.201 \pm 0.016$ & $0.529 \pm 0.101$ & $0.456 \pm 0.085$ & $0.329 \pm 0.029$ & DLS \\
\hline Zeta potential value [mV] & $-7.96 \pm 0.610$ & $-10.9 \pm 0.586$ & $-11.0 \pm 0.551$ & $-11.5 \pm 0.702$ & $-11.5 \pm 1.01$ & $-10.6 \pm 1.19$ & DLS \\
\hline Conductivity $[\mathrm{mS} / \mathrm{cm}]$ & $15.0 \pm 1.28$ & $14.7 \pm 0.513$ & $14.6 \pm 0.551$ & $14.2 \pm 0.503$ & $14.1 \pm 0.451$ & $15.1 \pm 1.10$ & viscometer \\
\hline Basic viscometer reading in percent [\%] & 5.4 & 6 & 5.1 & 6.5 & 4.3 & 5.9 & viscometer \\
\hline Calculated viscosity [CPS] & 1.41 & 1.54 & 1.31 & 1.67 & 1.33 & 1.55 & viscometer \\
\hline Calculated shear stress (SS) [dynes/cm2] & 1.43 & 1.4 & 1.18 & 1.5 & 1.28 & 1.38 & viscometer \\
\hline \multicolumn{8}{|l|}{ In $\mathrm{H} 2 \mathrm{O}$} \\
\hline Hydrodynamic size [nm] & ND & $941 \pm 57.14$ & $364.5 \pm 7.382$ & $1267 \pm 195.3$ & $1492 \pm 75.62$ & ND & DLS \\
\hline Polydispersity index & ND & $0.423 \pm 0.038$ & $0.211 \pm 0.022$ & $0.769 \pm 0.113$ & $0.623 \pm 0.148$ & ND & DLS \\
\hline Zeta potential value [mV] & ND & $-27.8 \pm 0.300$ & $-30.1 \pm 0.493$ & $11.7 \pm 0.208$ & $21.2 \pm 1.07$ & ND & DLS \\
\hline Conductivity $[\mathrm{mS} / \mathrm{cm}]$ & ND & $0.0107 \pm 0.00907$ & $0.00434 \pm 1.16 \mathrm{e}-4$ & $0.0188 \pm 0.0043$ & $0.00630 \pm 2.60 \mathrm{e}-4$ & ND & viscometer \\
\hline Basic viscometer reading in percent [\%] & 0.41 & 4.8 & 4.8 & 4.3 & 4.8 & ND & viscometer \\
\hline Calculated viscosity [CPS] & 1.05 & 1.23 & 1.23 & 1.1 & 1.2 & ND & viscometer \\
\hline Calculated shear stress (SS) [dynes/cm2] & 0.94 & 1.1 & 1.1 & 0.96 & 1.08 & ND & viscometer \\
\hline
\end{tabular}

${ }^{*} n-\mathrm{TiO}_{2}$ in $\mathrm{H}_{2} \mathrm{O}$ very large particles ==> refer to quality report

${ }^{* *} n-\mathrm{ZnO}$ the size is not correct, multimodal size distribution ==> refer to quality report

***b-ZnO there are also some very large particles with hydrodynamic size of several microns in both cRPMI and $\mathrm{H}_{2} \mathrm{O},==>$ refer to quality report

\section{Supplementary Table S2}

Lists of the differentially expressed genes from the microarray experiment at $6 \mathrm{~h}$ time point. To the excel file.

\section{Supplementary Table S3}

Lists of the differentially expressed genes from the microarray experiment at $6 \mathrm{~h}$ time point. To the excel file. 
Tables

Table 1. Particle characteristics provided by manufacturers.

\begin{tabular}{ccccccc}
\hline & n-TiO & b-TiO & n-ZnO & b-ZnO & n-Ag & i-Ag \\
\hline Type & nano & bulk & nano & bulk & nano & $\begin{array}{c}\text { nitric acid } \\
\text { silver(I) salt }\end{array}$ \\
Size & $30-40 \mathrm{~nm}$ & $<44 \propto \mathrm{m}$ & $20 \mathrm{~nm}$ & $240-350 \mathrm{~nm}$ & $20+/-3 \mathrm{~nm}$ & - \\
Form & Particle & Particle & Particle & Particle & Dispersion in $\mathrm{H}_{2} \mathrm{O}$ & - \\
Phase & $90: 10 *$ & $95: 5 *$ & - & - & - & - \\
SSA & $30(23) \mathrm{m}^{2} / \mathrm{g} * *$ & $8 \mathrm{~m}^{2} / \mathrm{g}$ & $50 \mathrm{~m}^{2} / \mathrm{g}$ & $4.5-6 \mathrm{~m}^{2} / \mathrm{g}$ & $27.4 \mathrm{~m}^{2} / \mathrm{g}$ & - \\
Purity & $99 \%$ & $99 \%$ & $99.50 \%$ & Not provided & $99.99 \%$ & $>99 \%$ \\
Coating & - & - & - & - & Polyvinylpyrrol- \\
Dissolution & Not provided & Not provided & Not & Not provided & 1 ppb - 2 ppm/ $\mathrm{H}_{2} \mathrm{O}$ & - \\
\hline
\end{tabular}

*Ratio of anatase:rutile.

**Specific surface area (SSA) of $\mathrm{TiO}_{2}$ was $30 \mathrm{~m}^{2} / \mathrm{g}$ according to the vendor but later confirmed $23 \mathrm{~m}^{2} / \mathrm{g}$.

Table 2. Sizes of particle and their agglomerates studied by transmission electron microscopy.

\begin{tabular}{cccccccc}
\hline & \multicolumn{3}{c}{ Primary particle [nm] } & & \multicolumn{3}{c}{ Agglomerate [nm] } \\
\cline { 2 - 4 } \cline { 6 - 7 } \cline { 5 - 7 } & Size range [nm] & GMD +/-SD [nm] & Counts & & Size range [nm] GMD +/- SD [nm] & Counts \\
\hline n-TiO2 & $17.9-151.1$ & $39.7 \pm 16.6$ & 157 & & $59.7-903.0$ & $273.7 \pm 230.0$ & 34 \\
b-TiO2 & $51.7-274.6$ & $135.6 \pm 48.7$ & 244 & & $187.6-1927.4$ & $621.0 \pm 382.6$ & 40 \\
n-ZnO & $5.0-32.3$ & $15.6 \pm 5.1$ & 157 & & $25.7-661.4$ & $126.1 \pm 154.8$ & 49 \\
b-ZnO & $48.9-549.4$ & $203.6 \pm 119.4$ & 98 & & $140.2-2256.6$ & $751.0 \pm 544.6$ & 28 \\
\hline
\end{tabular}

GMD, Geometric mean diameter; SD, standard deviation 


\section{Figure captions}

Figure 1. Cytotoxicity of the particles on differentiated THP-1 cells by MTT assay. (A) Percentage of viable cells after $24 \mathrm{~h}$ exposure of different materials determined by MTT assay showed that all the other particles, except both $\mathrm{TiO}_{2}$ reduced cell viability. (B) Schematic view of the set-up where particles were given to cells for $24 \mathrm{~h}$, or they were first incubated at $37^{\circ} \mathrm{C}$ for $24 \mathrm{~h}$, centrifuged and after that the yielded supernatant were given to cells for $24 \mathrm{~h}$. (C) Percentage of viable cells after $24 \mathrm{~h}$ exposure to $\mathrm{n}-\mathrm{ZnO}, \mathrm{b}-\mathrm{ZnO}$, n-PVP-Ag and to the corresponding, centrifuged supernatants (released ionic fractions) determined by MTT assay. Values were the mean \pm SD of 3 replicas. Significance indicated by $* \mathrm{P}<0.05, * * \mathrm{P}<0.01, * * * \mathrm{P}<0.001, * * * * \mathrm{P}<0.0001$ determined by two-way ANOVA. Cell exposure protocol for assessing cytotoxicity of extracellular ion release adopted from (Gliga et al., 2014).

Figure 2. Hierarchical clustering, principal component analysis (PCA) and Venn diagrams of different particles at $6 \mathrm{~h}$ and at $24 \mathrm{~h}$ time points. (A) Log2 gene expression intensities of different particles at both time points were hierarchically clustered using the Perseus software tool. (B) Principal component analysis (PCA) shows the clustering of different particles at different time points. (C) Venn diagrams demonstrate differentially up- and down-regulated genes (post hoc adj. P $<0.05$, linear $\mathrm{FC}>|1.5|$ ) when a nano-sized particle is compared to it bulk-sized or ionic control particle in differentiated THP-1 cells at $6 \mathrm{~h}$ or $24 \mathrm{~h}$ time point. The number of genes that are specific to n-Ag (437 and 818 genes) and to b-Zn (687 and 167 genes) are notably higher than the common genes or genes specific for i-Ag and n-Zn at $6 \mathrm{~h}$ and $24 \mathrm{~h}$, respectively. C, non-treated control cells.

Figure 3. Analysis of DEGs at $6 \mathrm{~h}$. (A) At the $6 \mathrm{~h}$ time point, the b-Zn and n-Ag groups formed a cluster, and all the other samples clustered together. The Z-score standardized gene expression 
intensities of the top 50 DEGs are shown in a heatplot, red indicating upregulation of gene expression and green indicating downregulation of gene expression. (B) Venn diagram of $\mathrm{ZnO}$ and $\mathrm{Ag}$ particles show four statistically significant (adjusted $\mathrm{p}$ value $<0.01$ ) group of genes, which play role in leucocyte activation and migration (443 genes), ionic responses (11 genes), innate immunity responses (112 genes) and in protein folding (183 genes).

Figure 4. Analysis of DEGs at 24h. (A) At the $24 \mathrm{~h}$ time point, $\mathrm{n}-\mathrm{Ag}$ samples formed an own cluster, b-Zn and $\mathrm{n}-\mathrm{Zn}$ formed a middle cluster, and all the other samples formed the third clustered. The top 50 DEGs are shown in heatplot, red indicating upregulation of gene expression and green indicating downregulation of gene expression. (B) Venn diagram of $\mathrm{ZnO}$ and $\mathrm{Ag}$ particles show four statistically significant (adjusted p-value $<0.01$ ) group of genes, which play role in lymphocyte activation (62 genes), hormone metabolic processes (78 genes), ionic responses (77 genes) and in virus response (671 genes).

Figure 5. Involvement of DEGs on GO pathways. Clustergram of the top ten GO pathways with up to 20 most significant input genes revealed a cluster metallothioneins both at $6 \mathrm{~h}$ and $24 \mathrm{~h}(\mathrm{~A}-\mathrm{B})$, and separate clusters for chemotaxis (C) and virus responses.

Figure 6. Validation by RT-PCR. The expression profiles of MT1F, CXCL8 and CCL20 genes were confirmed by RT-PCR analyses. 


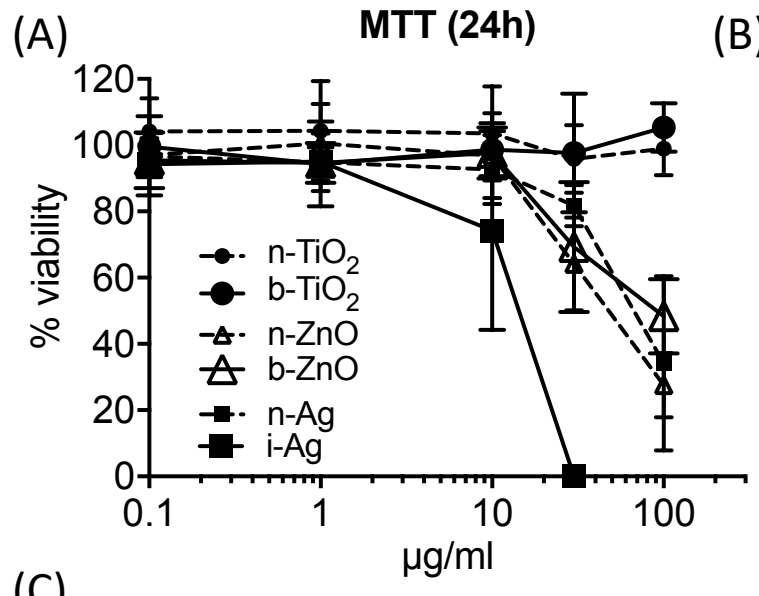

(B) $\mathrm{n}-\mathrm{ZnO}, \mathrm{b}-\mathrm{ZnO}$ or $\mathrm{n}$-Ag dispersion

(C)
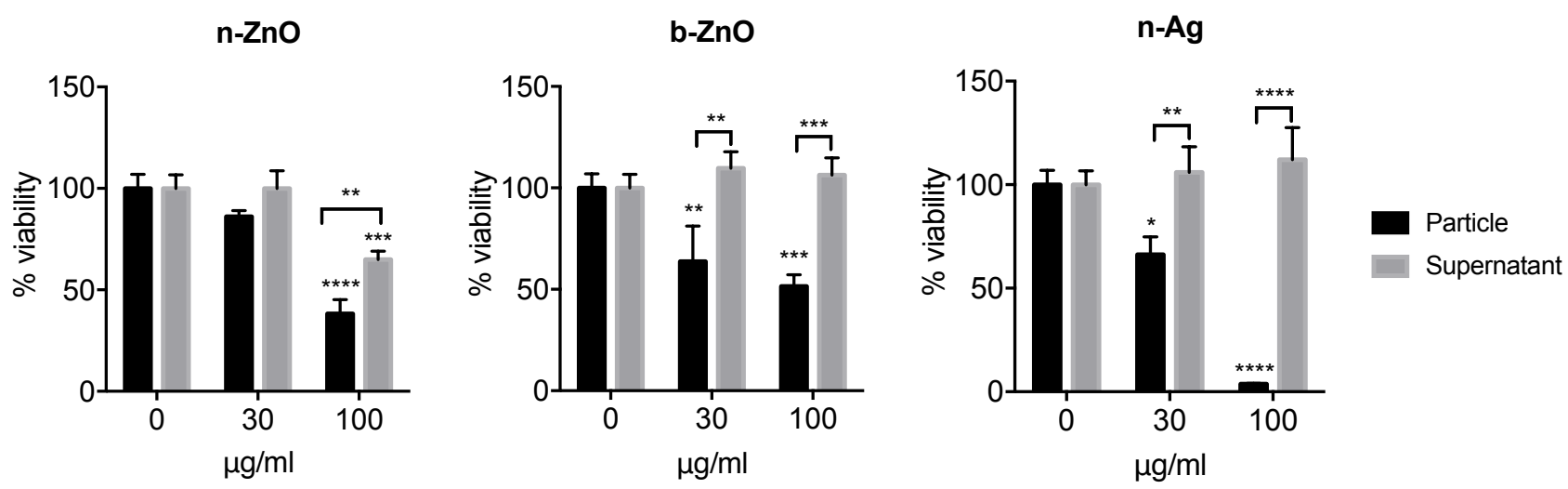

Figure 1 
(A)

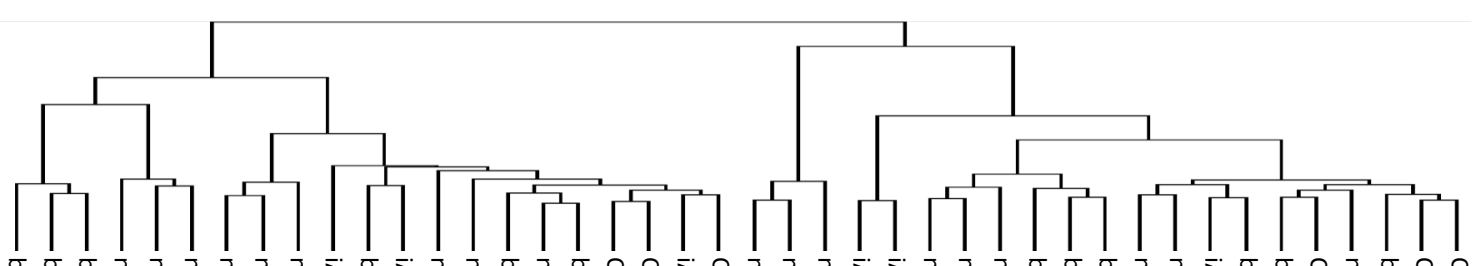

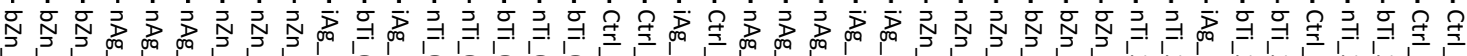

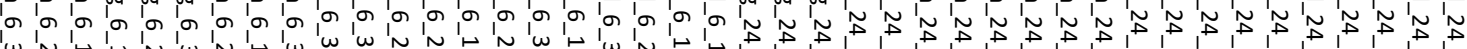

(B)

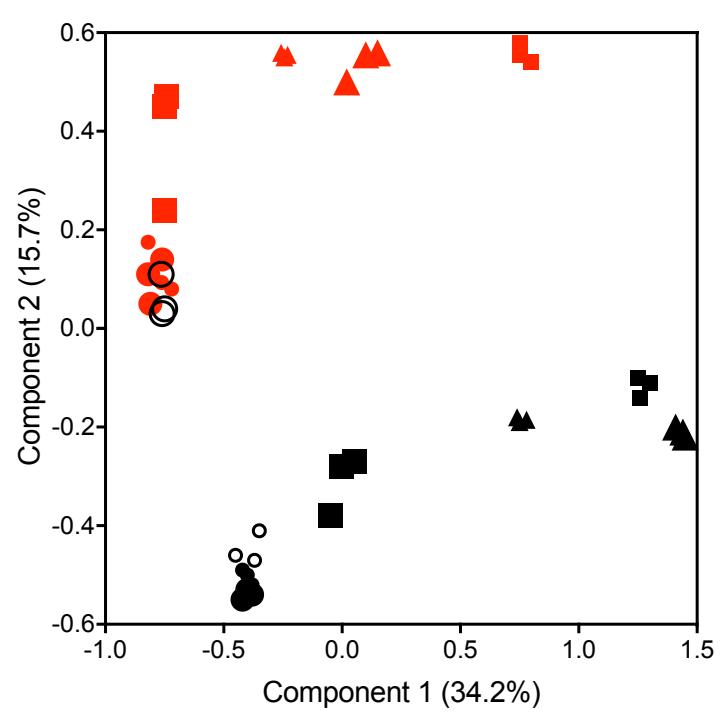
- Ctrl_6 O Ctrl_24
- nTi_6 nTi_24
- bTi_6 bTi_24
$\Delta$ nZn_6 $\quad \Delta \quad n Z n \_24$
$\triangle$ bZn_6 $\quad \Delta$ bZn_24
- nAg_6 nAg_24
iAg_6 iAg_24

(C)

iAg_6 vs C_6 nAg_6 vs C_6 iAg_24 vs C_24 nAg_24 vs C_24
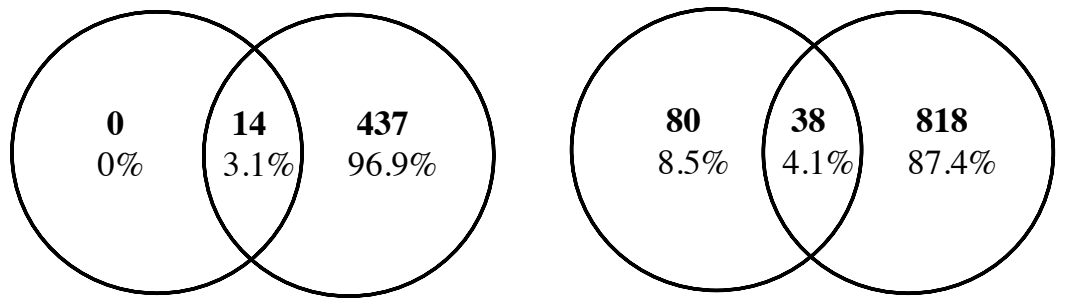

bZn_6 vs C_6 nZn_6 vs C_6

bZn_24 vs C_24 nZn_24 vs C_24
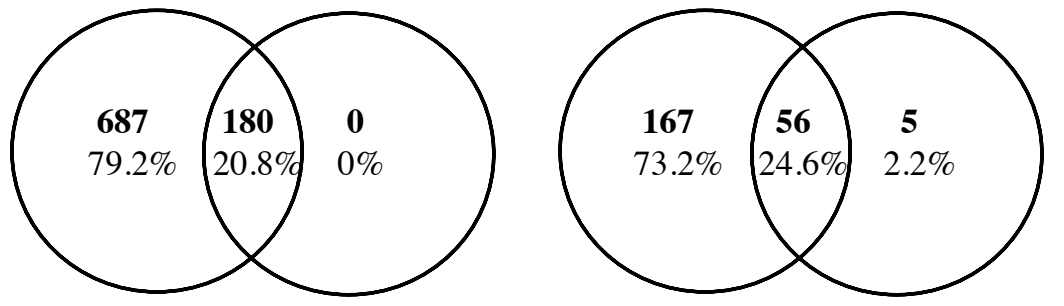

Figure 2 
(A)

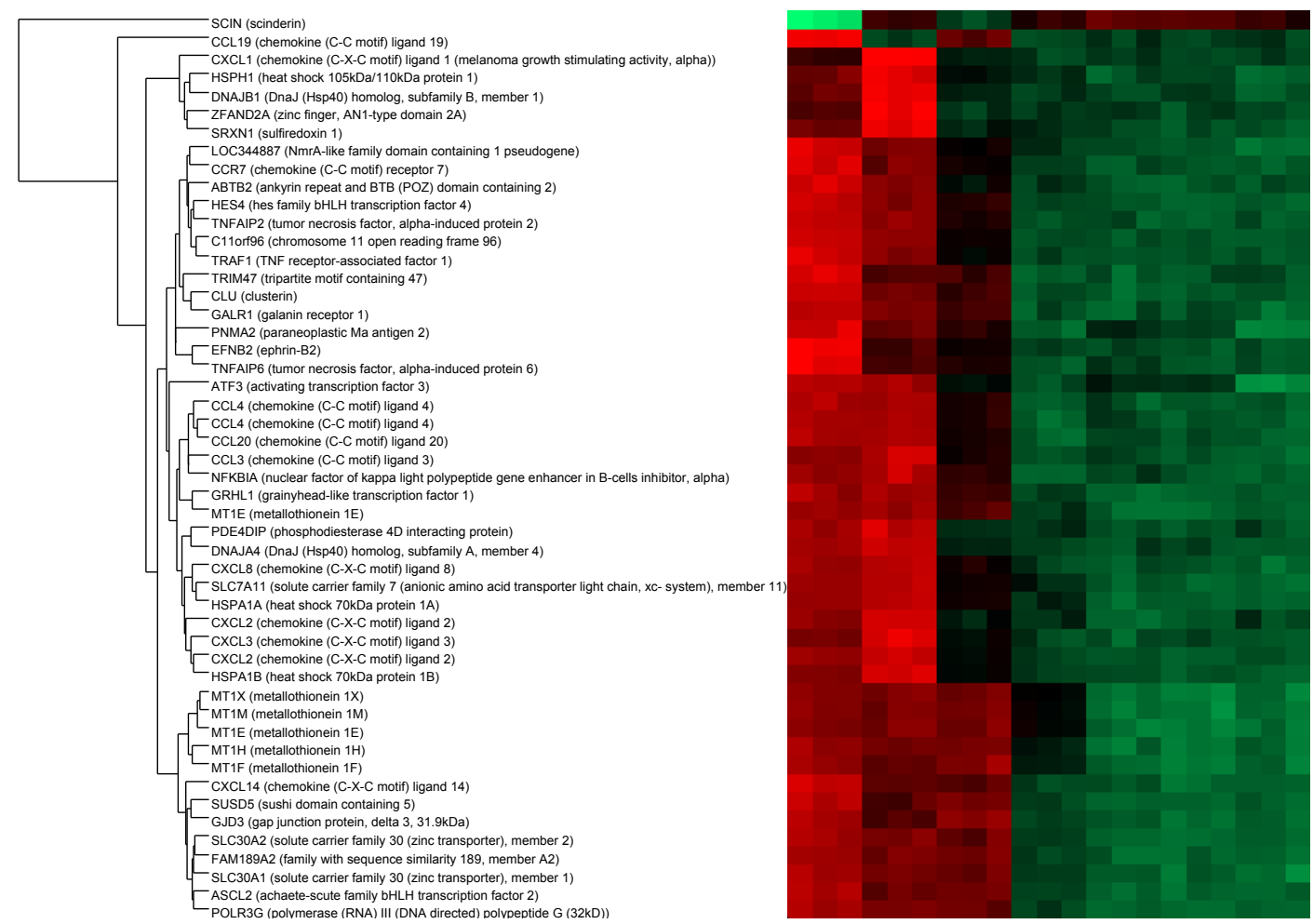

(B)

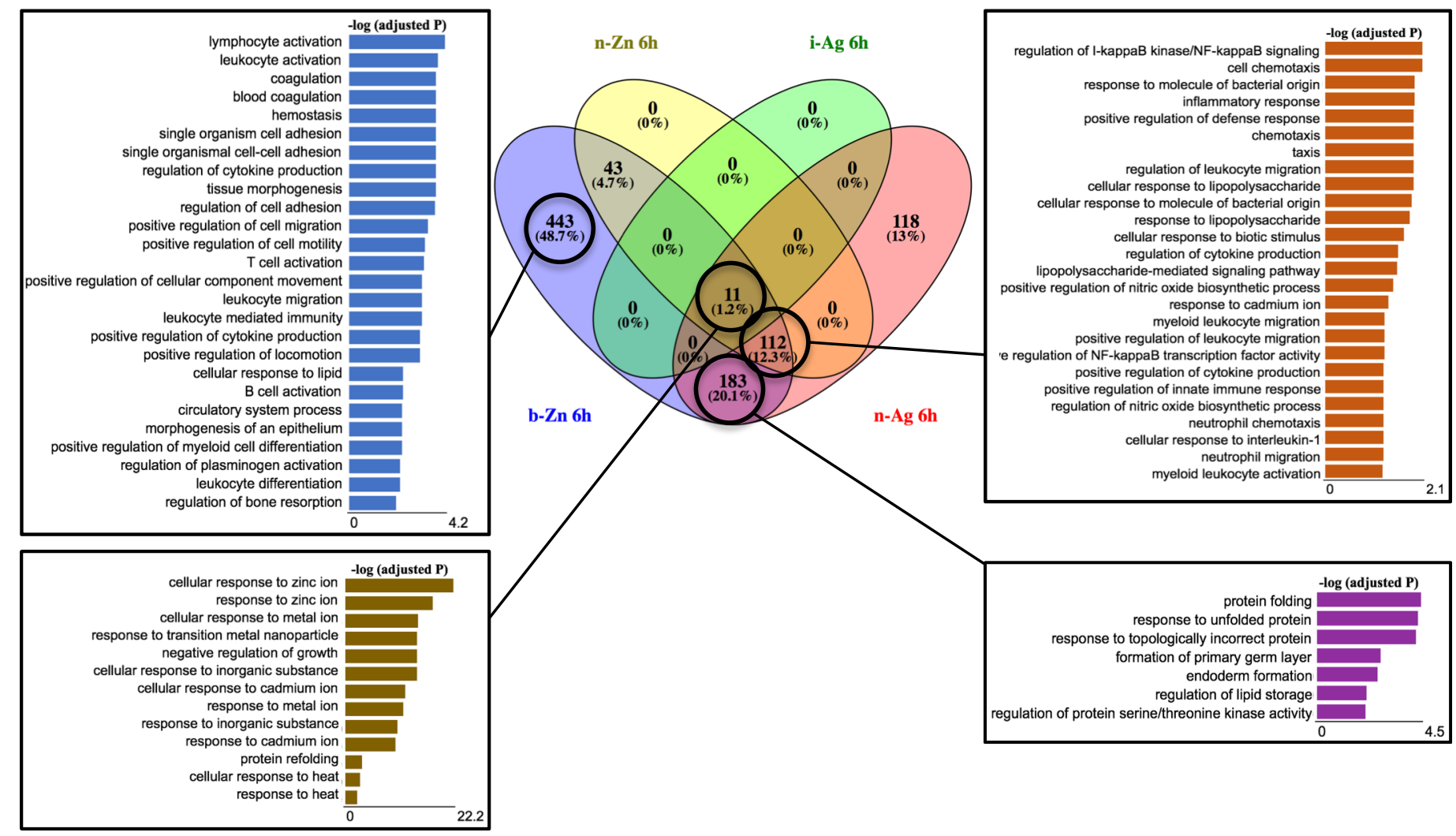

Figure 3 

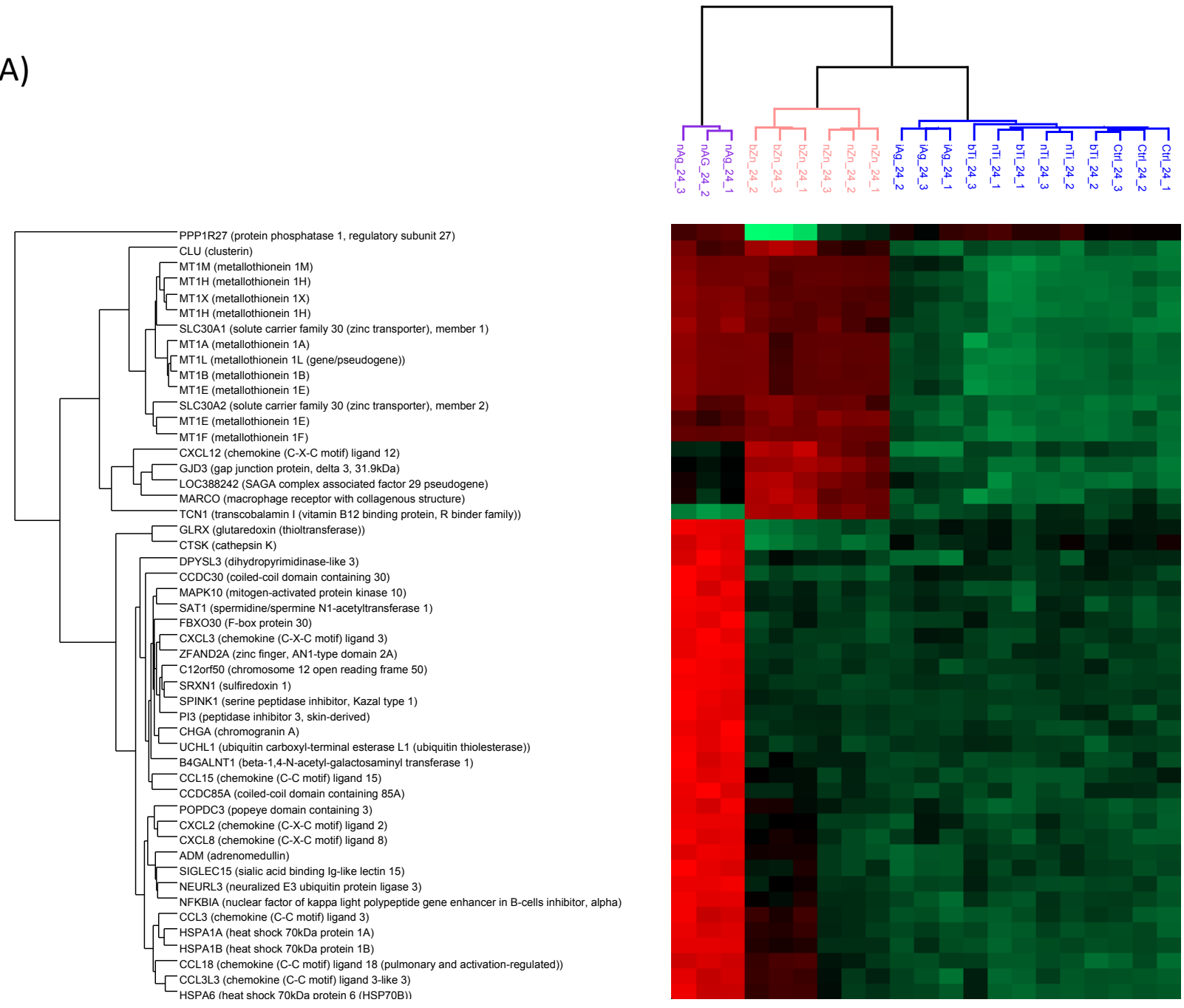

(B)

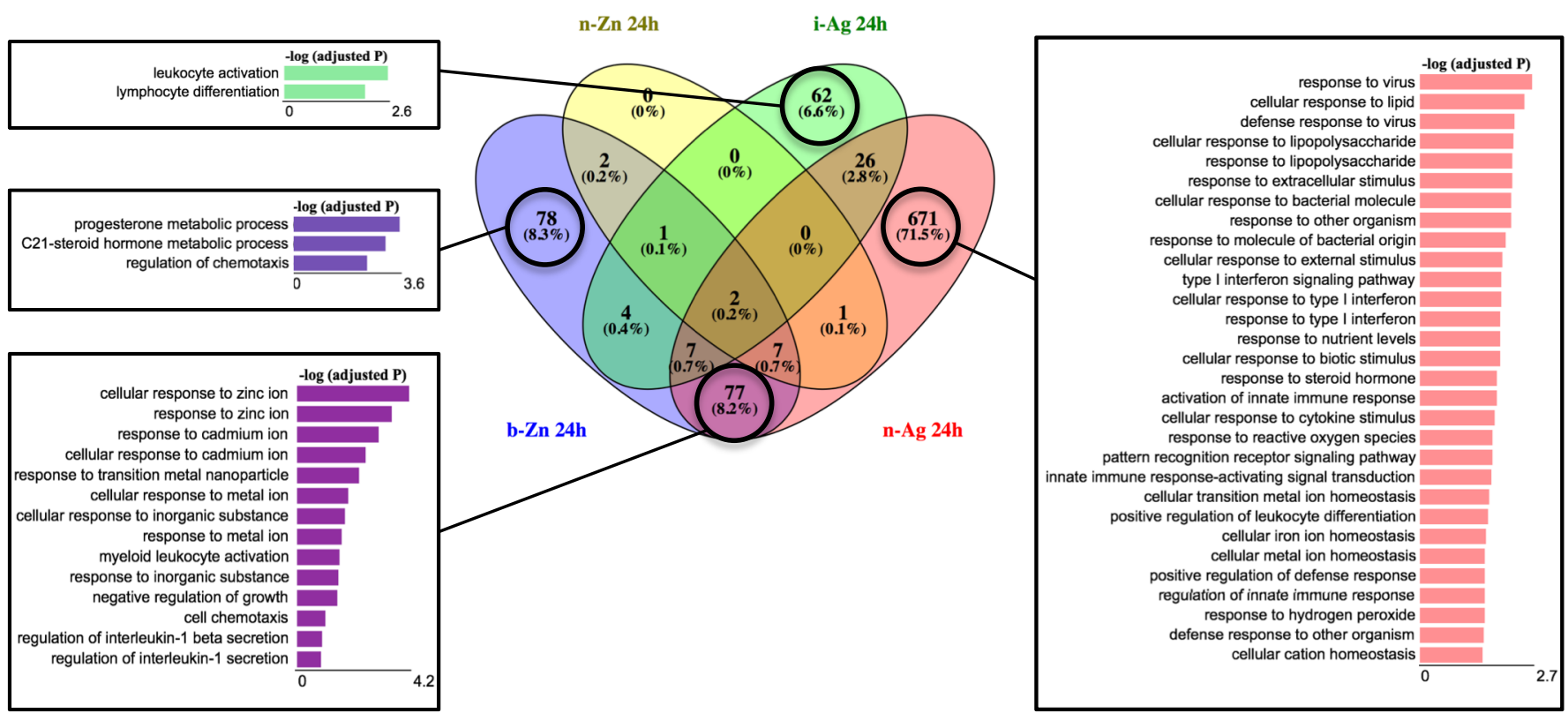

Figure 4 
12345678910

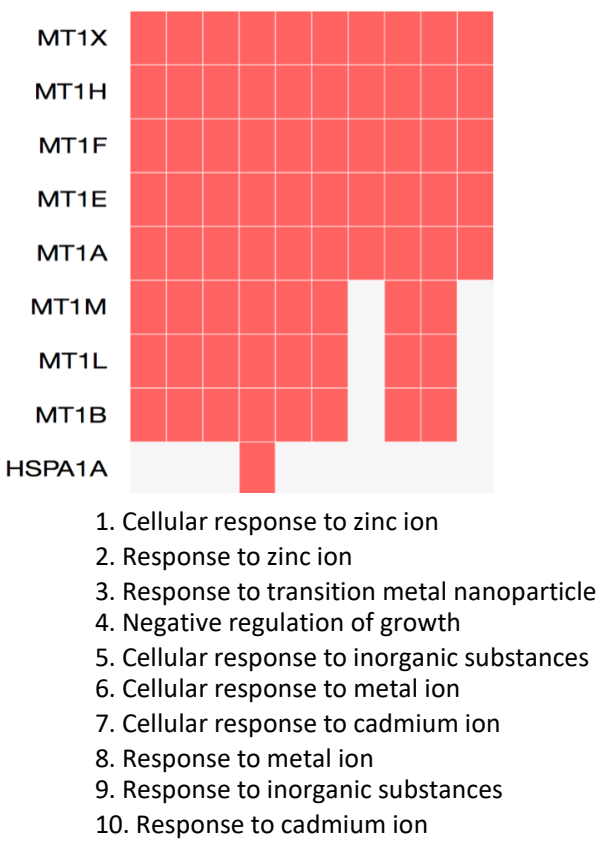

(B) b-Zn and n-Ag at $24 \mathrm{~h}$ (77 genes)

122345678910

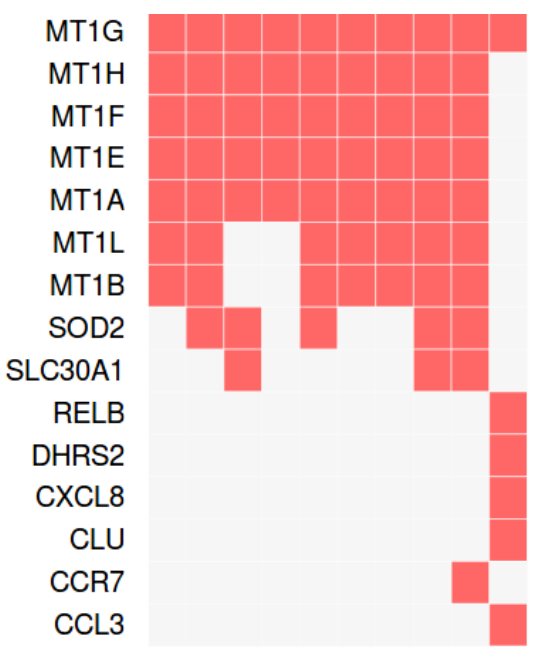

1. Cellular response to zinc ion

2. Response to zinc ion

3. Response to cadmium ion

4. Cellular response to cadmium ion

5. Response to transition metal nanoparticle

6. Cellular response to metal ion

7. Cellular response to inorganic substances

8. Response to metal ion

9. Response to inorganic substances

10. Myeloid leukocyte activation

\section{0}

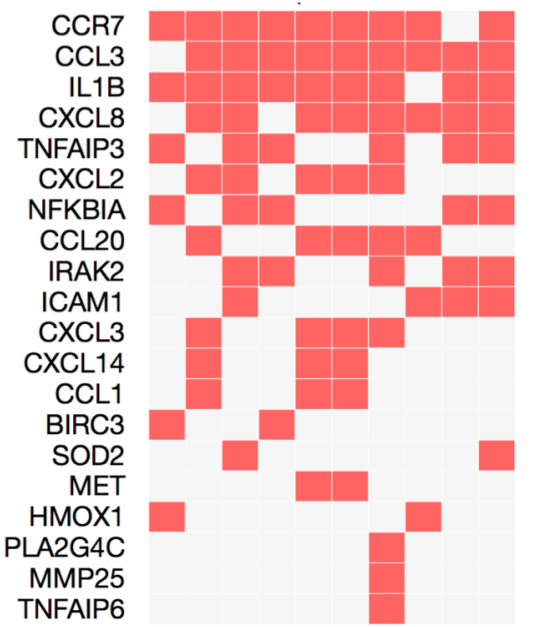

1. Regulation of I-kB/NF-kB signalling

2. Cell chemotaxis

3. Response to molecule of bacterial origin

4. positivie regulation to defense response

5. Chemotaxis

6. Taxis

7. Inflammatory response

8. Regulation of leucosyte migration

9. Cellular response to LPS

10. Response to LPS

(D)

\section{$\mathrm{n}-\mathrm{Ag}$ at $24 \mathrm{~h}$ (671 genes)}

$$
12345678910
$$

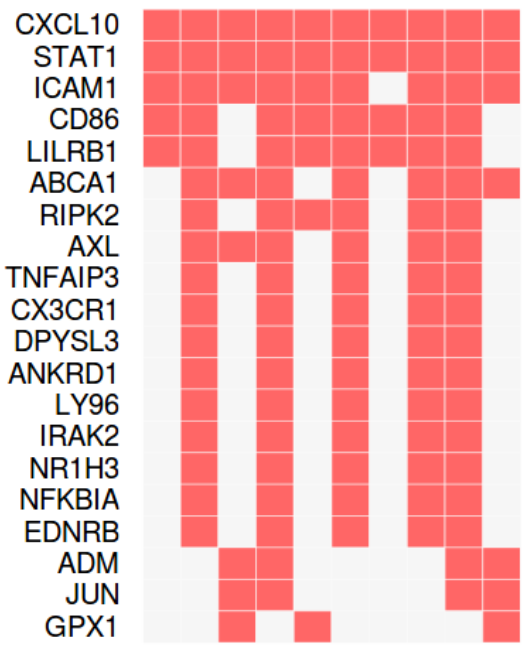

\section{Response to virus}

2. Cellular response to lipid

3. Response to lipopolysaccharide

4. Response to extracellular stimulus

5. Response to other organism

6. Cellular response to lipopolysaccharide

7. Defense response to virus

8. Cellular response to bacterial molecule 9. Response to molecule of bacterial origin 10. Response to type I interferon 
(A)
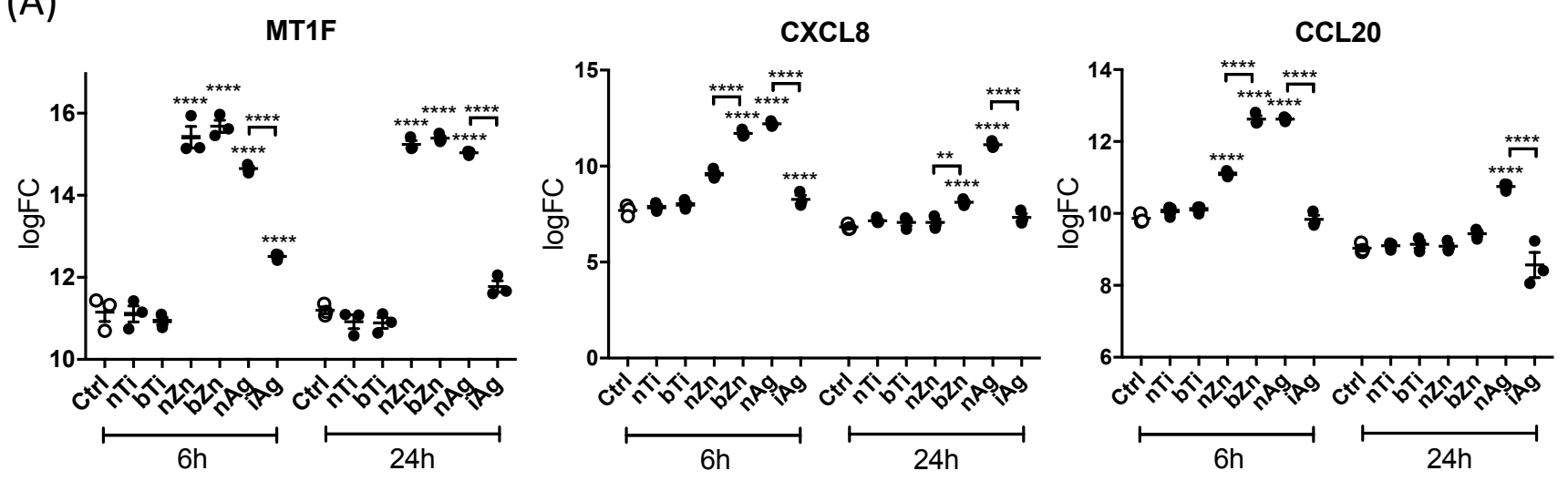

(B)
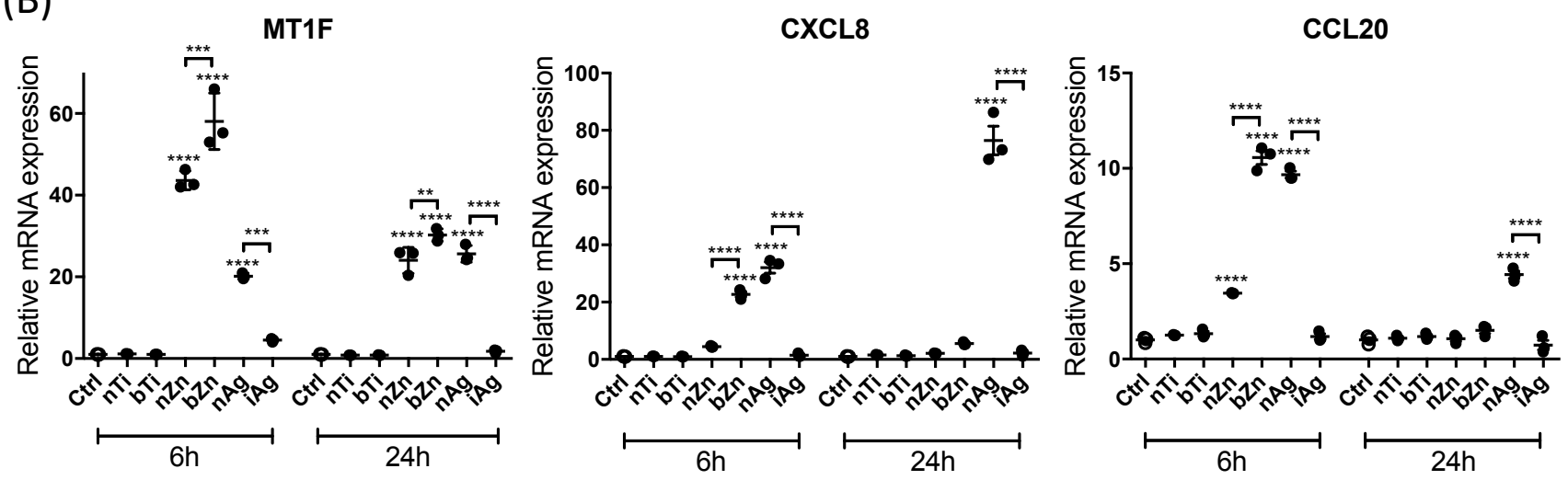

Figure 6 